This is a post-peer-review, pre-copyedit version of an article published in Climate Dynamics. The final authenticated version is available online at: https://doi.org/10.1007/s00382-021-05742-8 


\title{
Assessing precipitation extremes (1981-2018) and deep convective activity (2002-2018) in the Amazon region with CHIRPS and AMSU data
}

(Accepted on 20 March 2021; Published online 5 April 2021.)

\author{
Beatriz M. Funatsu ${ }^{1 *}$. Renan Le Roux ${ }^{2}$. \\ Damien Arvor ${ }^{3}$. Jhan Carlo Espinoza ${ }^{4}$. \\ Chantal Claud $^{5}$. Josyane Ronchail ${ }^{6}$. \\ Véronique Michot $^{7}$. Vincent Dubreuil ${ }^{3}$ \\ Received: date / Accepted: date
}

\begin{abstract}
The frequency and spatial distributions of precipitation extremes (PEs) and deep convective clouds (DCC) across the Amazon region were assessed using satellite-derived data. For PEs, CHIRPS dataset for the period 1981-2018 were used to calculate a set of absolute, threshold, duration, and percentile-based threshold indices defined by the Expert Team on Climate Change Detection and Indices. DCC occurrence was assessed based on the Advanced Microwave Sounding Unit data for the period 2002-2018. In northern Amazon (north of $5^{\circ} \mathrm{S}$ ) PEs and DCC are more frequent ( $\geq 60 \%$ frequency) during February-June. Averaged trends over these months have shown increase in daily rainfall above $20 \mathrm{~mm}$ of near 3 days over the 1981-2018 period, and an increase of 2 consecutive wet days ( $\mathrm{P}$ $\geq 1 \mathrm{~mm}$ ) in the same period. South of $5^{\circ} \mathrm{S}$ prevalence of PEs and DCC is largely observed during November-March ( $\geq 60 \%$ frequency), whereas the longest persistence of dry days is observed during June-August. Though all PE trends point to an intensification of rainfall in November-March, only consecutive dry days in
\end{abstract}

1* CNRS, Université de Nantes, UMR6554 LETG, Chemin de la Censive du Tertre BP 81227, 44312 Nantes cedex 3, France

E-mail: beatriz.funatsu@univ-nantes.fr

${ }^{2}$ CIRAD - Forêts et Sociétés, F-34398 Montpellier, France

${ }^{3}$ CNRS, Université Rennes 2, UMR6554 LETG COSTEL, Rennes, France

${ }^{4}$ IGE Univ. Grenoble Alpes, IRD, CNRS UMR 5001 / UR 252, Grenoble, France

${ }^{5}$ Laboratoire de Météorologie Dynamique, Sorbonne Université, École Normale Supérieure, IPSL Research University, Ecole Polytechnique, CNRS, LMD/IPSL, 75005 Paris, France

${ }^{6}$ Université de Paris, GHES, UMR 7159 LOCEAN, France

7 Laboratoire Atmosphères, Milieux, Observations Spatiales (LATMOS/IPSL), UVSQ, Université Paris-Saclay, France 
winter (JJA) and spring (SON) show significant trends, pointing to an increase of 7 days over the 38-yr winters. Rainfall extremes over the entire Amazon region were found to be moderate to strongly correlated with the mean vertically integrated moisture divergence, and in southern Amazon also to upper level divergence and upward vertical velocity. Increased frequency of DCC were found over the whole basin $\left(\sim 18 \% \cdot \mathrm{yr}^{-1}\right)$, in contrast to decreased convective overshooting (up to $\sim 15.4 \%$. $\mathrm{yr}^{-1}$ ).

Keywords Precipitation extremes - Deep convective clouds · Climatology · Trends · Amazon

\section{Introduction}

Precipitation is key parameter that characterizes the climate in the Amazon region. A major feature of precipitation in this region is the large spatial variability, which in turn, is further modulated by several modes of temporal variability (decadal, inter-annual, intra-seasonal, etc.; see, e.g., Nobre et al., 2009; Wang et al., 2018; Michot, 2017). Extreme precipitation events such as droughts and heavy precipitation are part of the natural variability of the climate system, however the frequency of precipitation extremes is expected to increase in the context of climate change (Cox et al., 2008; Fischer et al., 2014; Boisier et al., 2015). Several recent studies have pointed to a seemingly increase in the frequency of "once-in-a-century"-type events of floods and droughts (e.g., Marengo and Espinoza, 2016; Espinoza et al., 2019a; Barichivich et al., 2018; Towner et al., 2020) and communities across the basin perceive changes in climate and precipitation patterns occurring in the last decade (Funatsu et al., 2019). Yet, the large spatial rainfall variability and a lack of long-term climate records make it challenging to detect changes in precipitation patterns and even more so in the frequency of extreme events in the Amazon region.

In most of the Amazon region, rainfall has a predominantly seasonal character (e.g., Ronchail et al., 2006; Espinoza Villar et al., 2009; Andreoli et al., 2012; Michot, 2017; Arvor et al., 2017; Michot et al., 2018). In the southern part (roughly south of $5^{\circ} \mathrm{S}$ ) the rainy season is between November and March, with a peak in austral summer (December-February, DJF), and the dry season has a core in the winter months (June-August, JJA). Over the northern part of the basin the rainy season is more spatially varied, but it is mostly concentrated from May to October, and the driest period in DJF. In most of the basin, the rainfall seasonality is linked to the onset and demise of the so-called South America Monsoon System (SAMS; e.g., Jones and Carvalho, 2002; Gan et al., 2004; Vera et al., 2006), with fluctuations in precipitation frequency, intensity and amounts primarily linked to the variability of its features. Near the surface, westward trade winds transport water vapor from the Atlantic through the Amazon basin, with significant water vapour recycling through evapotranspiration along the way (Zemp et al., 2014); these easterlies are then deflected southwards as they approach the Andes mountains, transporting water vapor toward the La Plata Basin and the Andean mountains through a northerly low-level jet (LLJ) (Nogués-Paegle and Mo, 1997; Marengo et al., 2004; Martinez and Dominguez, 2014; Espinoza et al., 2020). The central and southern parts of the Amazon region are also affected by the South 
Atlantic Convergence Zone (SACS; Kodama, 1992, 1993; Carvalho et al., 2004; de Oliveira Vieira et al., 2013; Ambrizzi and Ferraz, 2015; Rosa et al., 2020), which consists of an elongated northwest-southeast oriented axis of clouds and precipitation, with a 10-day half-period of convection, that reaches the South Atlantic subtropics over a stretch of more than $4000 \mathrm{~km}$. The low level convergence and transient moisture transport from the Amazon along its northwestern edge increase both low-level potential temperature and convective instability, and contribute to the maintenance of the SACZ. de Oliveira Vieira et al. (2013) showed through a composite analysis that the SACZ episodes caused increased precipitation intensity in the southern Amazon via an anomalous cyclonic circulation and $35 \%$ stronger moisture convergence over the region (with important moisture recycling or evaporation from the forest). Variations in the (climatological) position of the SACZ and moisture availability have thus the potential to modify precipitation frequency, persistence and amounts in southern Amazon.

The El Niño-Southern Oscillation (ENSO) has been recognized as the main driver of interannual climate extremes in the Amazon (e.g., Rao and Hada, 1990; Ronchail et al., 2002, 2005; Ronchail and Gallaire, 2006; Paegle and Mo, 2002; Jiménez-Muñoz et al., 2016; Marengo, 2004; Marengo and Espinoza, 2016; Espinoza et al., 2019b). In general, the positive (negative) ENSO phase is related with precipitation decrease (increase), although the signal may not be homogeneous across the basin (Jimenez et al., 2018; Towner et al., 2020). This picture is complicated by the modulation of the ENSO effect by decadal and multi-decadal SST variability (e.g., Kayano and Andreoli, 2007; Cox et al., 2008; Marengo et al., 2011; Zeng et al., 2008; Yoon and Zeng, 2010; Andreoli et al., 2012; Gloor et al., 2013; Fernandes et al., 2015; McGregor et al., 2014; Michot, 2017; Wang et al., 2018; Kayano and Capistrano, 2014; Kayano et al., 2020; Jimenez et al., 2019; Towner et al., 2020). However, the combined tropical Pacific and Atlantic SST variability explains little more than $50 \%$ of interannual precipitation variance over the Amazon (Nobre et al., 2009; Yoon and Zeng, 2010), while the remaining variance is likely related to land surface processes and the variability of transient features from the south (Nobre et al., 2009; Siqueira and Toledo Machado, 2004; Yin et al., 2014).

Recent studies have indicated an increase in precipitation and in the number of wet days in the northern Amazon and decrease in precipitation and more dry days in the southern Amazon (Dubreuil et al., 2012; Fu et al., 2013; Debortoli et al., 2015, 2017; Arias et al., 2015; Espinoza et al., 2019a; Leite-Filho et al., 2020; Wang et al., 2018; Segura et al., 2020; Haghtalab et al., 2020). These changes in precipitation have been linked to a warm SST configuration in the Tropical North Atlantic, which increases the oceanic moisture supply advected inland, particularly over the northern Amazon, and to anomalies in the position and intensity of the upward branch of the Hadley and Walker circulations (Gloor et al., 2013; Arias et al., 2015; Wang et al., 2018; Barichivich et al., 2018; Espinoza et al., 2019a; Segura et al., 2020). Haghtalab et al. (2020) show that significant trends of mean annual precipitation and very heavy precipitation have been found basin-wide, with increase in precipitation in the western side and drying in the southern and eastern parts. The decrease in precipitation in the southern Amazon is compounded by enhanced wind subsidence over this region (Leite-Filho et al., 2020; Espinoza et al., 2019a) and also by a southward shift of both the subtropical jet (Fu et al., 2013) and the SACZ (Zilli et al., 2019) with associated decrease (increase) in precipitation at the 
northern (southern) edge of its climatological position. In addition, the frequency and intensity of the LLJ in the northern Andes has substantially increased in the last 39 years (Jones, 2019; Segura et al., 2020), leading to enhanced precipitation in Bolivia on the eastern Andes slopes and over the Altiplano. Other elements that contribute to the precipitation variability at various spatial and temporal scales include transient features such as mesoscale convective systems and fronts (Siqueira and Toledo Machado, 2004) and the Madden-Julien Oscillation (Nogués-Paegle and Mo, 1997; Jones and Carvalho, 2002; Mayta et al., 2018, 2020). Finally, land cover changes due to deforestation and subsequent land use may locally amplify the global climate changes effects by changing local (thermo)dynamics, reducing regional water vapor recycling and transport (Sampaio et al., 2007; Correia et al., 2008; Lawrence and Vandecar, 2015; Nobre et al., 2016; Wright et al., 2017; Zemp et al., 2017a,b; Marengo et al., 2008; Baker and Spracklen, 2019; Staal et al., 2020), and leading to a shortening of the rainy season (Debortoli et al., 2017; Leite-Filho et al., 2020). Deforestation exacerbates the effects of droughts and increases the vulnerability of remaining forests to the effects of dieback (Nobre et al., 2009; Bagley et al., 2013; Gloor et al., 2015; Zemp et al., 2017a,b), generating a positive feedback effect.

While several studies aforementioned have documented increased precipitation in the northern and northwestern Amazon, and lengthening of dry season in the southern Amazon, a comprehensive climatological description of precipitation extremes in the whole region has not yet been presented. There also remains a question whether there exists significant trends in extreme precipitation frequency and/or intensity in the Amazon region. As previously mentioned, a challenge to study climate extremes in this region regards the lack of long term, reliable climatic measurements. The recent release of the Climate Hazards Group InfraRed Precipitation with Station data (CHIRPS) rainfall gridded product, which has daily temporal resolution covering nearly four decades (early 1980's to present) provides an opportunity to investigate this issue in a systematic framework, based on standard indices that measure both dry and wet precipitation extremes. This dataset has been recently used by Espinoza et al. (2019a) and Haghtalab et al. (2020), who studied spatial patterns in precipitation trends across the Amazon basin, including episodes of heavy and very heavy precipitation (rainfall above 10 and $20 \mathrm{~mm}$, respectively). Our approach goes a step further by assessing patterns and changes not only in the frequency of heavy rainfall, but also persistence (both of wet and dry days) and intensity of precipitation, providing a global view of PEs and their changes across the basin.

In addition to extreme precipitation indices, we also investigate convective activity in the region. Both shallow and deep convective clouds are ubiquitous in the Tropical region, and are important for the atmospheric energy budget and hydrological cycles. Deep convective clouds are an essential feature of the SAMS system (e.g., Lenters and Cook, 1997; Vera et al., 2006), and although not linearly correlated to precipitation, they carry the potential for intense rainfall (Wendisch et al., 2016; Rysman et al., 2016). They may also be interpreted as an inverse proxy, that is, their prolonged absence is indicative of very dry and/or stable atmospheric conditions. Convective overshooting (COV) clouds are, by definition, deep convective plumes that overshoot the level of neutral buoyancy. They represent a subset of deep convective clouds occurring mainly over land in the Tropical region and reaching higher in altitude due to intense updrafts (Hong et al., 2005; 
Rysman et al., 2016; Funatsu et al., 2018). Beyond their potential for high impact weather, they also contribute to water vapor and short-lived chemical compound transport across the tropopause. Changes in their frequency and spatial coverage thus impact the atmospheric chemistry and dynamics. It is thus essential to map and characterize deep convective activity in the Amazon region, and all the more so as their spatio-temporal distribution may respond to forcing due to land cover changes (e.g., Funatsu et al., 2012; Wendisch et al., 2016; Baker and Spracklen, 2019). To the authors best knowledge this aspect of convective activity over the Amazon has not been presented before.

The main objectives or this study are: 1) to present a comprehensive climatology of precipitation extremes (PEs) and deep convective activity (DCA) in the Amazon region, and 2) estimate trends at basin scale. We aim at characterizing the spatial distribution of PEs and DCA, and identify regions that are more vulnerable to changes in their patterns. In the following, we describe the data sets (Section 2) and analysis methods (Section 3) used in the study. Section 4 presents the mean spatial distribution of PEs and DCA, and their trends, at both annual and seasonal scales, with a discussion on the results and conclusions presented in Section 5 .

\section{Data}

\subsection{CHIRPSv2}

The Climate Hazards Group InfraRed Precipitation with Station data (CHIRPS) rainfall gridded product combines $0.05^{\circ}$ high spatial resolution satellite imagery and in-situ station data, providing near-global $\left(50^{\circ} \mathrm{N}-50^{\circ} \mathrm{S}\right.$; all longitudes) daily precipitation estimates (Funk et al., 2015). We used Version 2 data from 1981 to 2018 , at a spatial resolution of $0.25^{\circ}$ latitude $\times 0.25^{\circ}$ longitude; a 1-year period was defined from August to July of the following year. The 37-year mean annual precipitation features, together with the study area comprising the Amazon basin and the most of the Brazilian Legal Amazon, is shown in Figure 1; its standard deviation, as well as examples of precipitation anomalies for recent events are shown in Supplementary Material Figure S1. These maps show that CHIRPS is able to reproduce the main characteristics of the mean precipitation over the domain (Fig. 1; see, e.g. Arvor et al. 2017, for PERSIANN-CDR, Haghtalab et al. 2020 and Paca et al., for CHIRPS and ground-base datad, and Dubreuil et al. for TRMM), as well as anomalous precipitation events (Fig. S1b-e). An area over northern Peru was found to have precipitation estimates with a shifted baseline after 2011 that necessitates a longer time series to be confirmed; this region, marked in dark dots in Fig. 1, was discarded in the statistical analysis.

Comparisons between CHIRPS and the interpolated HYBAM (www.ore-hybam.org) observed precipitation data (HOP) have been conducted by Paccini et al. (2018), and a recent study by (Cavalcante et al., 2020) provided a comparison between monthly mean rainfall estimated by CHIRPS and data measured at 45 ground stations in the Amazon region. Cavalcante et al. (2020) concluded that they are in good agreement though CHIRPS tends to underestimate large rainfall totals; this translates into an overall underestimation of extreme rainfall indices, compared to those derived from in situ data. Espinoza et al. (2019a) have shown a remarkable 
agreement between trends of heavy precipitation and dry days estimates derived from CHIRPS and the HOP datasets, and Haghtalab et al. (2020) shows also good correlation between CHIRPS and ground-based data from the Brazilian National Water Agency (ANA). This suggests that even though the indices may be underestimated, trends estimates may be reliable assuming that the bias is relatively constant in time.

\subsection{AMSU-B/MHS}

In addition to rainfall from CHIRPS, we analysed deep convection and convective overshooting based on data from the Advanced Microwave Sounding Unit module B (AMSU-B) and the Microwave Sounding Unit (MHS), which operate onboard polar-orbiting NOAA and MetOp satellites. AMSU was first launched onboard NOAA-15 (N15); data is available from 1999 onwards. From 2005 AMSU-B was replaced by the Microwave Sounding Unit (MHS) on board NOAA-18 (N18) and NOAA-19 (N19), and it operates also on MetOp-A (M02), -B (M01), and -C, starting in 2007, 2013 and 2018, respectively. The equatorial crossing times for each platform are shown in Fig. 2 (notice that only the ascending or descending track is shown).

AMSU-B and MHS are cross-track scanning radiometers, a spatial resolution of $16 \mathrm{~km}$ at near-nadir and of $\sim 52 \mathrm{~km}$ (along track) $\times 27 \mathrm{~km}$ (cross-track) at the furthest field of view positions. The AMSU-B/MHS intruments have 5 channels, three of which have frequencies near $183 \mathrm{GHz}$ (water vapor absorption line), and is designed for optimal moisture retrieval. MHS differs from AMSU-B in which the highest-frequency channel was changed from $183 \pm 7$ to $190 \mathrm{GHz}$; this change does not cause a significant impact in the analysis of DCA, as shown, e.g., by Claud et al. (2012). We refer to NOAA KLM User's guide (available at http://www.ncdc.noaa.gov/oa/pod-guide/ncdc/docs/klm/index.htm), and to Funatsu et al. (2018) and references therein, for details on the instrument, calibration and known issues. Because deep convective clouds present a clear diurnal cycle over continental areas (Funatsu et al., 2012), a constant reading hour is required to examine long-term variations. We use AMSU-B/MHS data from N17, M02 and M01 covering the period of 2002-2018. During this period, N17 (2002-2009) and MetOp (2007-2018) have close equatorial crossing time sampling convective activity around the same local time every day, twice daily (AM and PM: between 10-10:30 LT for N17 before 2008, and between 9-10 LT after that, and at 9:30 for both MetOp platforms; Fig. 2), thus reducing the impact of different diurnal sampling by drifting NOAA platforms. Finally, periods with problematic data have been removed, as in Funatsu et al. (2018).

\subsection{Reanalysis data}

ERA5 reanalysis (Hersbach et al., 2020) wind, divergence and moisture data for the period 1981-2018 were used to assess the large-scale atmospheric conditions. Specifically, low-level horizontal winds averaged over the 1000-850 hPa layer (LLu and LLv), upper-level (300-100 hPa) vertical velocity (UL $\omega)$ and upper-level divergence (ULd), and the mean vertically integrated moisture divergence (MVIMD). 
The latter is useful as it gives a combined information of dynamical (wind) and thermodynamical (moisture) effects; high negative values of this parameter (i.e. large moisture convergence) can be related to precipitation intensification and potentially, to floods.

\section{Methods}

\subsection{Precipitation Indices}

We computed extreme precipitation indices defined by the World Climate Research Program (WCRP) Expert Team of Climate Change Detection and Indices (ETCCDI; https://www.wcrp-climate.org/etccdi; see also Alexander et al., 2006; Sillmann et al., 2013) to characterize PEs. The ETCCDI indices describe moderate climate extremes with re-occurrence times of a year or shorter. These indices comprise: (1) absolute indices, which describe the annual maximum 1 day or (accumulated) 5 day precipitation amounts, (2) heavy precipitation threshold indices, which count the number of days that a particular daily precipitation value is attained or exceeded (e.g., daily rainfall above $20 \mathrm{~mm}$ ), (3) duration indices, which describe the longest length of wet (CWD) and dry (CDD) spells, and (4) percentile-based threshold indices, which describe the occurrence of precipitation exceeding a high percentile threshold, usually 95th or 99th percentile. The list and definition of indices used in this study is presented in Table 1. For the CDD parameter (longest sequence of consecutive dry days), and for this parameter only, the period of January to December (instead of August to July) was considered in order to re-center the hydrological year on the southern Amazon dry season (JJA; Espinoza Villar et al., 2009).

\subsection{Deep convective and convective overshooting clouds}

The presence of liquid and/or frozen hydrometeors cause a depression in the microwave radiation measured by MHS scanning frequencies at $183.3 \pm 1,183.3 \pm 3$, $190 \mathrm{GHz}$ (channels 3-5, respectively). Based on these microwave properties, Hong et al. (2005) proposed a set of criteria for detecting deep convective (DC) and convective overshooting (COV) clouds in the tropical region. These criteria were validated for the Tropics, and subsequently applied to study DCA in the southern Amazon (Funatsu et al., 2012) and in the Mediterranean region as well (e.g., Funatsu et al., 2009, 2018, and references therein).

In the present study we follow the method described in Funatsu et al. (2012) and Funatsu et al. (2018), to which we refer for full details. A brief description is presented here. First, the original, spatially irregular MHS brightness temperature data were first interpolated to a $0.25^{\circ} \times 0.25^{\circ}$ regular latitude $\times$ longitude grid Then, a flag for DC or COV occurrence using Hong et al. (2005) criteria was assigned for each grid point. Finally, the number of DC or COV occurrences for each hour was re-sampled to a $2.25^{\circ} \times 2.25^{\circ} \mathrm{mesh}$, and the number of valid grid points (i.e., grid points with an actual measurement) was retained. Then, for each satellite, the monthly mean COV frequency was computed by dividing the total number of $\mathrm{COV}$ grid points by the number of valid grid points in the month. 
Finally, an average for all satellites was performed thus taking in account the number of satellites.

Even though a direct link between deep convective clouds (as detected with Hong et al. (2005) method) and precipitation amounts is not established, analysis of DC and COV provide indication of vigorousness of the convective activity, and thus on the potential for precipitation. Figure S2 shows the spatial distribution of anomalies of DC frequency for the same years as shown in Figs. S1b-e. Given the different baseline period of mean calculation and the different metrics, there is a remarkable spatial agreement between precipitation and deep convective anomalies, confirming the suitability of DC and COV as proxies to detect precipitation anomalies.

\subsection{Trend and correlation analyses}

Trends for DC, COV, and for each of the precipitation indices in Table 1 were assessed for each gridpoint in the domain using a linear regression model. Robustness of trends was assessed by estimating the $95 \%$ confidence interval. The linear approach is arguable as a choice to evaluate trends in a highly non-linear system (and even more so regarding PEs), but it has been widely used, for example, in IPCC Assessment Reports, to describe and assess recent changes. A linear regression was thus chosen as a first-order approximation model to investigate a general trend, with the confidence interval providing a gauge for the reliability of the signal.

We also used the Spearman rank correlations to measure the degree of monotonic relationship between precipitation indices (also convective activity) and atmospheric variables, in seasonal timescale. That is, the time series for each index was correlated with the time series of the mean vertical integral of moisture divergence (MVIMD), low level wind components (LLu and LLv), upper level divergence (ULd) and upper level vertical velocity (UL $\omega)$. Even if general, averaged atmospheric conditions are not enough to explain the occurrence of a particular extreme event, this analysis will provide insight on the background conditions that can help explain PEs and DCA occurrences.

All trend analysis and correlations were performed based on normalized values for each variable. The normalization was performed by subtracting the mean over the period 1981-2018 for PEs and 2002-2018 for DC and COV, and dividing the result by the corresponding standard deviation. Notice that the period considered in this study concerns only that after the climate shift around the 1970s observed in South America (Carvalho et al., 2011; Jacques-Coper and Garreaud, 2015), thus excluding periods of heavy rainfall and runoff in parts of the basin in the 1970s (e.g. Callède et al., 2004; Espinoza Villar et al., 2009).

\section{Results}

\subsection{Spatio-temporal distribution of PEs}

Figure 3 shows the mean spatial distribution of indices listed in Table 1 . The mean yearly accumulated precipitation above the 37-yr 95th percentile (P95w, Fig 3a) 
and maximum 5-day accumulated precipitation (RX5day, Fig 3c) show a spatial pattern similar to that of the annual simple day intensity index (ASDII; Fig 3e), with larger values at the northeastern and northwestern edges of the basin, and over the Amazon-Andes transition region, which has been identified as a rainfall hotspot area (Espinoza et al., 2015; Chavez and Takahashi, 2017). There is also a relative maximum of these indices over southeast Amazonas (AM) and northern Mato Grosso (MT) states in BR, with a northwest-southeast axis, close to the climatological position of the SACZ at the southeastern edge (Carvalho et al., 2004). The frequency of very wet days (R95wp, RR $\geq 95$ th percentile; Fig 3b) is higher in the north/northwest and decrease towards the south/southeast and along the eastern and southwestern basin edges. R95wp ranges from around 11 days a year in the NW region, decreasing to 5-8 days in the southernmost areas of the domain. The spatial distribution of R20mm shows a contrasted north-south frequency, with nearly $50 \%$ more occurrences in the northern region compared to southern Amazon. R20mm has a typical yearly occurrence of 30-45 days in the northern Amazon, whereas in the southern and southeastern Amazon the typical yearly frequency is of 10-20 days. ASDII shows a weaker spatial gradient, indicating that rainfall is spread over a longer rainy season in the north, thus "diluting" the daily rainfall intensity. The maximum number of consecutive dry days (CDD; Fig 3f) follows an expected spatial distribution of longer dry periods towards the south/southeast and short duration in the northern region (shortest at NW). In the northwest, CDD typically lasts only 5 days a year, whereas in the southeast (Mato Grosso - MT, Tocantins - TO, and south of Maranhão - MA states) it can reach more than 60 days.

In complement to the spatial distribution, Fig. 4 shows the months when occurrences of R95wp, RX5day and R20mm were most frequently detected throughout the considered period. There is a noticeable north-south dichotomy in seasonal scale, with the southern part showing preferred modes in January, February and March, and the northern part (roughly north of $5{ }^{\circ} \mathrm{S}$ ) spread from February to June (more frequently found in April and May). R95wp and RX5day frequencies fall within the "mode months" in above $60 \%$ of the cases in most of the domain (Fig. 4b,d), except notably for parts of the Amazonas state and northern Peru; occurrences of R20mm are however more spread along the year in the northern half (Fig. 4f). Only in the southern and eastern Brazilian states within the Legal Amazon region do R20mm occur in a proportion larger than $60 \%$ in the given mode months. Areas with weak proportion of R20mm in the mode months correspond to those where mean $\mathrm{R} 20 \mathrm{~mm}$ is over 30 days in northwestern Amazon, where very heavy precipitation is rather frequent. CWD and R1mm show maxima in the NW Amazon and minima in the southern and southeastern margins and R99wp is qualitatively similar to R95wp (not shown).

Both CWD and CDD are particular metrics that provide a distinctive portrait of rainfall extremes, as they measure the persistence of dry or wet spells. For a large portion of the southern Amazon (south PA, MT, TO states, and southern Bolivia), where rainy and dry seasons are well defined, the mean first day of CDD is observed in June, while in the northern Pará (PA) and Amapá (AP) states (northeastern Amazon) the longest CDD period appears in August-September (Fig. 5a). In the northern and northwestern Amazon the first day of CDD shows a large standard deviation (Fig. 5c), of 45 days or higher. CWD starts predominantly in January in most of the region (Fig. 5b). In southern Amazon the standard deviation of the 
first day of CWD (Fig. 5d) is of about 30-45 days, which is two to three times larger than for CDD (Fig. 5c), and reflects the large variability in the frequency of rain at the beginning of the rainy season (also shown by Arias et al., 2015; Arvor et al., 2017) in this region.

\subsection{Deep convective activity}

The mean annual frequency of DC and COV clouds are shown in Figure 6. The mean DC clouds distribution follows largely that of mean precipitation (see Fig. 1), with frequency maximum over the northwest region and along the eastern flanks of the Andes, and decreasing southwards and eastwards. COV presents a roughly similar spatial pattern, however spatial frequency gradients are subtler (see color scale spacing). We observe also that the median COV frequency corresponds to approximately $13 \%$ of the DC median frequency, but in the NW region COV can represent, on average, nearly $18 \%$ of the deep convective clouds. Whereas in the northern Amazon DC and COV occurs in the most intense precipitation mode months (April and May), in the southern part, DC and COV can be frequently found as early as October, and throughout February (Fig. 7). The high month-tomonth and inter-annual variability of convective activity are illustrated in Figures 8 and S2, which shows the time series of COV and DC, respectively, averaged over the northern and southern Amazon region. These figures show that DC and COV frequencies north of $5^{\circ} \mathrm{S}$ were reduced during the droughts of 2005 and 2014-2015, but less so in the south; in 2008, a prolonged negative anomaly of COV (but not in DC clouds) is seen throughout 2008 in the south. The NW Amazon extreme floods of 2011/2012 are also evident in Fig.8; these years corresponds to maximum values of COV in the north. Large values of COV in 2014 in southern Amazon are probably related to the extreme floods in the Madeira Basin.

\subsection{Trends and correlation analyses}

Figure 9 shows the linear regression coefficients for each variable at each grid point in the domain; darker dots represent trends that are statistically significant $(95 \%$ confidence interval). Trends for ASDII, R95pw, Rx5day, and R20mm (Fig 9a-d) show regional agreement, with a generally congruent signal with respect to the total precipitation trend (not shown): Positive trends at the northern and western parts of the basin, and negative trends in parts of AM and in southern Bolivia. In terms of rainfall persistence (CWD) positive trends (that is, longer periods of rain) are found in the northern part of the domain, and the opposite in the southern Amazon (Fig 9e). In addition, significant CDD trends (Fig 9f) were found in most of the southern half of the domain (northern Rondônia - RO), MT, TO, and MA states in Brazil), with longer dry-day periods. Areas with significant negative trends (i.e., decreased persistence of dry-day periods) are found at northwestern Amazon.

In the previous section it was shown that precipitation extremes occur in preferred months, following the timing of the rainy season particularly in the southern half of the domain. We thus investigate trends concentrated in the seasons when they mostly occur: February to June in northern Amazon (north of $5^{\circ} \mathrm{S}$ ), 
and November to March in southern Amazon (south of $5^{\circ} \mathrm{S}$ ). CDD trends will be shown for southern Amazon dry season (JJA).

DC and COV trends are also presented in the context of seasonality due to the shorter time series and strong month-to-month variability. A spatial overview (Fig.10) evidences that deep convective activity shows contrasting trends for DC and COV: positive trends for DC frequency are found in the whole basin, whereas COV trends are predominantly negative, mostly in the rainy (October-May) season, but also in June-September though with larger spatial heterogeneity. No trends at grid point scale were found to be statistically significant due to high variability of DCA and the short time series available (18 years, combining N17, M01 and M02).

Considering averages over the domain in seasonal scale, the time series of PE indices (Figs.11 and 12) confirm the year-to-year variability of the magnitude of PEs and DCA due to SST anomalies (La Niña/El Niño years and flood/drought conditions marked in the figures). Over the northern part (Fig. 11), notable anomalous peaks were found in 1998 (RX5day, seasonal SDII - hereafter simply SDII, and R95wp), 1999 (R20mm and CWD), 1993 (R20mm and CWD), and 2014 (RX5day and R95wp). Those were caused by a combination of ENSO and Atlantic SST conditions (see Marengo et al. (2018); Towner et al. (2020) for details). Anomalously high frequency of DC clouds were observed in 2017, but there were no corresponding PE anomalies. R20mm and CWD show significant positive trends in the extended autumn season (Feb-Jun; Table 2(a)): $3.7 \pm 2.8 \% . \mathrm{yr}^{-1}$ and $3.0 \pm 2.9 \% \cdot \mathrm{yr}^{-1}$, respectively. This corresponds to an increase of about 4 -fold and 3-fold in the number of anomalous R20mm and CWD in the whole period, or in absolute terms, to an increase of $2.6 \pm 2.0$ days for R20mm and $2.0 \pm 1.9$ days for CWD in the analysed 37 years. Trends were not statistically significant for RX5day, R95wp or SDII. Deep convective clouds frequency were enhanced in the 17 years analysed, with an increase of $18.5 \pm 5.2 \% \cdot \mathrm{yr}^{-1}$, but COV has significantly decreased with a rate of $-12.3 \pm 8.9 \% \cdot \mathrm{yr}^{-1}$. Correlation analysis with large scale atmospheric parameters (Table $3(\mathrm{a})$ ) showed that R20mm is strongly linked to MVIMD $(\rho=-0.73)$, and to a lesser extent to LLu $(\rho=0.50)$ and ULd $(\rho=0.54)$. CWD has moderate correlation with ULd $(\rho=0.52)$ and a weaker link to MVIMD $(\rho=-0.36)$. R95wp variability in extended autumn was found to have significant correlations to MVIMD $(\rho=-0.49)$ and LLu $(\rho=0.41)$. MVIMD and DC were also found to have a moderate correlation $(\rho=-0.55)$. However, among the analysed large scale parameters only UL $\omega$ showed a robust (linear) trend in the period, with an increase of $5.1 \pm 2.5 \% \cdot \mathrm{yr}^{-1}$. Trends for weaker upward motion at upper levels may partially explain the decrease in COV frequency, as it depends on strong updrafts within DC clouds to occur.

In the southern part, notable PEs (Fig. 12) occurred in 1997/98 (that is, November 1997 to March 1998) with negative anomalies for all parameters coincident with years of extreme drought (EL Niño), and in 2013/14 with the highest R20mm, RX5day, SDII, R95wp, and DC positive anomalies coinciding with extreme flood in the upper Madeira river. However, PEs did not present significant trends (Table 2(b)), though a general tendency appears for increased rainfall extremes and SDII, and for decreased CWD. Similarly to the northern region, DC shows increased frequency $\left(18.3 \pm 5.4 \%\right.$.yr $\left.{ }^{-1}\right)$ and a stronger COV decrease $\left(-15.4 \pm 7.4 \% . \mathrm{yr}^{-1}\right)$. All PE indices for rain (R20mm, RX5day, SDII, CWD and P95wp) have a robust correlation with MVIMD $(\rho=-0.65,-0.49,-0.52,-0.49$ 
and -0.58 , respectively; Table $3(\mathrm{~b}))$, as well as DC $(\rho=-0.57)$. Similarly to the northern region, the only significant trend regarding the large scale atmospheric parameters concerns a positive trend for $\mathrm{UL} \omega\left(5.1 \pm 2.5 \% \cdot \mathrm{yr}^{-1}\right)$, that is, decreased upward motion at upper levels.

Regarding CDD in southern Amazon, a significant increase in the persistence of dry days in JJA is observed (Fig. 13), with a trend of $3.7 \pm 2.8 \%$.yr ${ }^{-1}$, or in absolute terms, an increase of $7.3 \pm 5.4$ days in the whole period. CDD have a robust correlation with MVIMD $(\rho=0.63), \operatorname{LLu}(\rho=0.49)$ and ULd $(\rho=-0.42)$. A significant decrease in COV cloud frequency $\left(-10.1 \pm 8.6 \% \cdot \mathrm{yr}^{-1}\right.$; Fig. $\left.13 \mathrm{c}\right)$ was also found in this season. However, none of the large-scale dynamical parameters present long-term trends in this season and region.

\section{Discussion and Conclusions}

Our trend analysis for R20mm is in very good agreement with those shown by Haghtalab et al. (2020), and qualitatively with the analysis of wet (R10mm) and dry days performed by Espinoza et al. (2019a), both of which used the MannKendall test to estimate trend signal. Our analysis showed that in the northern Amazon, changes in precipitation extremes are mostly observed in the R20mm (Fig. 9d and Table 2(a)), and these trends closely mimic those of the mean annual total precipitation, as shown by Haghtalab et al. (2020).

Further breaking the spatial features of PE trends, a decreasing trend in precipitation extremes was found in a northwest-southeast axis starting in the Brazilian state of Amazonas and extending towards the Brazilian southeast region (Fig. 9), with a disruption in MT. This pattern is congruent to that observed by Haghtalab et al. (2020) for R20mm; furthermore, the decrease in PEs in southeastern AM state coincides with a shift towards a drier climate observed with independent data (Dubreuil et al., 2019). Positive CDD trends (JJA) and decrease of RX5day, R20mm and SDII through September-May (not shown) in northern Rondônia reflects the regional dynamics of deforestation (Khanna et al., 2017), in which surface roughness decrease in response to deforestation leads to a shift from a thermodynamically driven regime to a dynamically driven one, with convection and precipitation suppression (enhancement) upwind (downwind) of deforested areas. The southeastern portion of the Amazon overlaps with the climatological position of the SACZ, which is responsible for part of rainfall totals in the region mostly during the period of December - March (Kodama, 1992, 1993; Carvalho et al., 2004; de Oliveira Vieira et al., 2013; Rosa et al., 2020). A recent study by Zilli et al. (2019) showed evidence of a southward displacement of the SACZ and reduced (increased) precipitation at its northern (southern) edge, which could explain the negative $\mathrm{PE}$ trends at the SE edge. These negative trends in $\mathrm{PE}$ are accompanied by reduction on COV (Fig. 10b,d), even though DC shows year-round positive trends across most of the region (Fig. 10a,c). This apparent incongruity between $\mathrm{PE}$ and DC trends is most likely due to the short-time series for DCA analysis, and analysis with a longer series and/or other data sets would be necessary to re-examine this issue.

Another region that come out as one where there is significant year-round reduction of PEs (for rainfall) is southern Bolivia. Espinoza et al. (2019a) and Leite-Filho et al. (2020) have linked the increase of dry days frequency in DJF 
in this region (south of $12.5^{\circ} \mathrm{S}$ ) to a decrease in both upper level divergence and (upward) vertical velocity, and our results also show that upper level vertical velocity $\omega$ has increased over southern Amazon in austral summer. Since PEs and DCA have a robust correlation with UL $\omega$ (and ULd and MVIMD) in this region, the negative upward vertical velocity trends may effectively contribute to the observed PE negative trends in this specific area in Nov-Feb.

The increase in R20mm, R95wp, RX5day and SDII in southern Peru, northern Bolivia and the state of Acre in BR (southwest AMZ; Fig.9) follows that in the mean precipitation in DJF, shown by Segura et al. (2020). They presented evidence that upward motion in the western tropical south America $\left(35^{\circ}-10^{\circ} \mathrm{N}, 60-80^{\circ} \mathrm{W}\right)$, including the southwest AMZ, has intensified, bringing more moisture to midtropospheric levels and decreasing static stability in the entire region. This largescale atmospheric feature has replaced the advection of momentum and moisture from the central Amazon at low levels, coupled with upper-level easterlies, as the dominant mode of atmospheric circulation in DJF, enhancing convection and precipitation. Further supporting their findings, we found that DC frequency has indeed substantially increased over this area, with an area of stronger positive trends qualitatively coinciding with a region of intense mid-tropospheric moisture and upward motion increase (see Fig. 10a and Fig. 5 of Segura et al. (2020)). The clear spatial dichotomy in ASDII, R95pw, RX5day and R20mm trends with decrease/increase in the southern/northern upper Madeira basin (Figure 9a-d) has been attributed to major changes in the hydrological system (Espinoza et al., 2019b).

The average increase (decrease) in $\mathrm{DC}(\mathrm{COV})$ clouds in all seasons must be interpreted with caution due to the still limited time series that constrains reliability particularly at grid point scale. While DC clouds show a link with MVIMD, and less strongly with ULd and UL $\omega$, COV seems to not be directly affected by these parameters (no significant correlations). One clue to the stronger decrease of COV during the rainy season in southern Amazonia is the decreased upward motion trend at upper levels (between 300-100hPa; also found by Espinoza et al. 2019a and Leite Filho et al. 2020 as previously noted) which suggests less favorable conditions for the strong updrafts necessary for overshoots. The launch of a third MetOp platform in late 2018 contributes to the continuity of these measurements, which will allow to revisit this trend assessment at a finer spatio-temporal scale, including trends taking into account the possible relationships between changes in land cover use and the frequency of DC and COV clouds.

The present study did not address the issue of attribution of trends to SST forcing and deforestation, for a number of reasons. In the case of oceanic forcing, ENSO has a strong impact in the year-to-year variability of precipitation in the region, however there are no significant trends in the amplitude of the ENSO signal, nor in the signal of the Pacific SST anomaly (long term trends can be seen in: https://climexp.knmi.nl/getindices.cgi?WMO=NOAAData/mei \&STATION=MEI), despite some evidence of increased La Niña-like conditions (Lian et al., 2018). Thus, adding an ENSO index in the regression analysis would increase the uncertainty of the trend estimate with little insight gain. Indeed, correlation analysis between precipitation extremes and ENSO indices (not shown) have confirmed the lack of statistical relevance of ENSO for the multi-decadal trends. 
Concerning Atlantic SST anomalies, previous studies have demonstrated that a steady warming trend in the northern tropical Atlantic SSTs since the 90's has led to increased precipitation frequency and amount in the northern Amazon region through the intensification of moisture transport (e.g., Gloor et al., 2013, 2015; Espinoza et al., 2019a). Increase in R10mm frequency in northern Amazon was found indeed to be positively correlated with a warm pool in the Tropical Atlantic, as well as with increased ascending motion and upward moisture transport between $0-5^{\circ} \mathrm{S}, 70^{\circ}-60^{\circ} \mathrm{W}$. This could also explain the increase in R20mm in the northern part of the domain, but a longer time series is necessary to firmly confirm the link of trends of North Atlantic SST to trends for all precipitation extremes indices.

In addition to a longer CDD in JJA, a positive trend was also observed in dry-to-wet transition season (SON: $2.9 \pm 1.8$ days in 37 years). This finding not only corroborates results from previous studies that have pointed to an increase frequency of dry days and the lengthening of the dry season in this region (Dubreuil et al., 2012; Fu et al., 2013; Debortoli et al., 2017; Arvor et al., 2017; Leite-Filho et al., 2020; Espinoza et al., 2019a), but it also highlights that dry conditions have become more persistent as well, worsening soil hydric stress conditions. This has important implications for agricultural practices in the region, which includes the most important producer of soybeans in the country (MT) as well as of cotton and maize (Arvor et al., 2012, 2014; Pires et al., 2016; Hampf et al., 2020; Caioni et al., 2020). These agricultural practices are greatly constrained by the dates of beginning of the rainy season (seeding), cloudiness (plant development), rainfall amounts and intensity (seeding, plant development, irrigation management), and duration of the rainy season (double cropping practices; that is, successive backto-back crop production). Prolonged dry conditions amplify differences between the energy balance components of the Amazon forest and croplands, leading to increased land surface temperature and decreased evapotranspiration over nonforested areas (Caioni et al., 2020), particularly over large-scale agricultural fields, thus reducing the capacity of vegetation to withstand droughts. If extended dry conditions force a delay in the beginning of the planting operation, the probability that double cropping is viable in this region will be strongly affected (Pires et al., 2016; Hampf et al., 2020). Research on cultivar genotypes that are either more resistant to droughts or that respond better than others to irrigation (Cotrim et al., 2020; Zuffo et al., 2020; Hampf et al., 2020) reflects the investment of the agricultural sector towards adaptation to changing climatic conditions. The proliferation of farm dams created in fluvial networks for fish farming or irrigation in MT state (Arvor et al., 2018) is another sign of efforts to control the supply of water availability, and to reduce the vulnerability of their economical activities to fluctuations in rainfall.

The increase in CDD along southern and eastern edges of the Amazon region in the dry and dry-to-wet transition seasons, qualitatively coincide with areas where deforestation were or still are rampant; nevertheless, however tempting it is to suggest a causality between them, an initial statistical analysis between land cover changes and changes in PEs did not yield any significant signal (not shown). Even though major droughts or intense precipitation/flood events in the region are primarily controlled by oceanic-atmospheric forcing (Towner et al., 2020), drought conditions may be particularly worsened by deforestation leading to a feedback that increases the vulnerability of remaining vegetation especially at the end of dry season (September-November; Bagley et al., 2013; Zemp et al., 2017b; Baker 
Table 1 List of precipitation indices, definitions, and units. Extreme precipitation indices source: http://etccdi.pacificclimate.org/list_27_indices.shtml, accessed on 5 August 2019.

\begin{tabular}{|c|c|c|c|}
\hline Index Label & Index name & Definition & Units \\
\hline $\mathrm{RR}$ & Precipitation & Daily convective rainfall amount & $\mathrm{mm}$ \\
\hline Rx5day & $\begin{array}{l}\text { Max 5-day precipita- } \\
\text { tion }\end{array}$ & $\begin{array}{l}\text { Let } \mathrm{RR}_{k j} \text { be the precipitation amount for the } \\
5 \text {-day interval ending } \mathrm{k} \text {, period } \mathrm{j} \text {. Then maxi- } \\
\text { mum } 5 \text {-day values for period } \mathrm{j} \text { are: } \mathrm{Rx} 5 \mathrm{day}_{j}= \\
\max \left(\mathrm{RR}_{k j}\right)\end{array}$ & $\mathrm{mm}$ \\
\hline $\mathrm{R} 1 \mathrm{~mm}$ & Wet days & Number of days where $R R \geq 1 \mathrm{~mm}$ & days \\
\hline $\mathrm{R} 20 \mathrm{~mm}$ & $\begin{array}{l}\text { Very heavy precipita- } \\
\text { tion days }\end{array}$ & $\begin{array}{l}\text { Let } \mathrm{RR}_{i j} \text { be the daily precipitation amount } \\
\text { on day i in period } \mathrm{j} \text {. Count the number of days } \\
\text { where } \mathrm{RR}_{i j} \geq 20 \mathrm{~mm}\end{array}$ & days \\
\hline SDII & Simple daily intensity & $\begin{array}{l}\text { Let } \mathrm{RR}_{w j} \text { be the daily precipitation amount } \\
\text { on wet days, } \mathrm{w}(\mathrm{RR} \geq 1 \mathrm{~mm} \text { ) in period } \mathrm{j} \text {. If } \\
\mathrm{R} 1 \mathrm{~mm}_{j} \text { represents number of wet days in } \mathrm{j} \text {, }\end{array}$ & mm.day ${ }^{-1}$ \\
\hline CDD & $\begin{array}{l}\text { Maximum number of } \\
\text { consecutive dry days } \\
(\mathrm{RR}<1 \mathrm{~mm})\end{array}$ & $\begin{array}{l}\text { then: } \mathrm{SDII}_{j}=\left(\sum_{1} \mathrm{R}_{j} R R_{w j}\right) / R 1 m m_{j} \\
\text { Let } \mathrm{RR}_{i j} \text { be the daily precipitation amount on } \\
\text { day } \mathrm{i} \text { in period } \mathrm{j} \text {. Count the largest number of } \\
\text { consecutive days where } \mathrm{RR}_{i j}<1 \mathrm{~mm}\end{array}$ & days \\
\hline CWD & $\begin{array}{l}\text { Maximum number of } \\
\text { consecutive wet days } \\
(\mathrm{RR} \geq 1 \mathrm{~mm})\end{array}$ & $\begin{array}{l}\text { Let } \mathrm{RR}_{i j} \text { be the daily precipitation amount on } \\
\text { day i in period j. Count the largest number of } \\
\text { consecutive days where } \mathrm{RR}_{i j} \geq 1 \mathrm{~mm}\end{array}$ & days \\
\hline P95w & $\begin{array}{l}\text { Very wet days precipi- } \\
\text { tation }\end{array}$ & $\begin{array}{l}\text { Let } \mathrm{RR}_{w j} \text { be the daily precipitation amount } \\
\text { on a wet day } \mathrm{w}(\mathrm{RR} \geq 1.0 \mathrm{~mm}) \text { in period } \mathrm{j} \\
\text { and let } \mathrm{P} 95 \mathrm{w} \text { be the } 95 \mathrm{th} \text { percentile of precip- } \\
\text { itation on wet days in the } 1981-2017 \text { period. } \\
\text { If } \mathrm{R} 1 \mathrm{~mm} \text { represents the number of wet days } \\
\text { in the period, then P95 } \mathrm{w}_{j}=\sum_{1}^{R 1 m_{j}} R R_{w j} \text {, } \\
\text { where } \mathrm{RR}_{w j} \geq \mathrm{P} 95 \mathrm{w}\end{array}$ & $\mathrm{mm}$ \\
\hline R95wp & Very wet days & $\begin{array}{l}\text { Let } \mathrm{RR}_{w j} \text { be the daily precipitation amount } \\
\text { on a wet day } \mathrm{w}(\mathrm{RR} \geq 1.0 \mathrm{~mm}) \text { in period } \mathrm{j} \\
\text { and let } \mathrm{P} 95 \mathrm{w} \text { be the } 95 \text { th percentile of precip- } \\
\text { itation on wet days in the } 1981-2017 \text { period. } \\
\text { If } \mathrm{R} 1 \mathrm{~mm} \text { represents the number of wet days } \\
\text { in the period, then } \mathrm{VWD}_{j}=\sum_{1}^{R 1 m_{j}} R R_{w j} \text {, } \\
\text { where } \mathrm{RR}_{w j} \geq \mathrm{P} 95 \mathrm{w}\end{array}$ & days \\
\hline
\end{tabular}

and Spracklen, 2019; Staal et al., 2020; Vilanova et al., 2020; Caioni et al., 2020). At the same time that technological progress is heavily relied upon to counter the effects of rising temperatures and precipitation pattern changes, there arises a paradox in which the very deforestation for crop and pasture expansion may be amplifying global climate change effects on local scale (Staal et al., 2020). To extricate the effects of deforestation from those of global climate change on extreme precipitation is a formidable challenge, and requires both statistical and mechanistic modelling approaches to analyse attribution issues.

Acknowledgements AMSU data was accessed through ICARE Data and Services Center with support of the IPSL-ESPRI team. BMF, RLR, DA and VD acknowledge the support of the program CLIMAT-AMSUD 21-CLIMAT-12. 
Table 2 Seasonal trends and 2-sigma (95\%) uncertainty for normalized PE indices averaged over the northern (north of $5^{\circ} \mathrm{S}$; NAM) and southern Amazon (south of of $5^{\circ} \mathrm{S}$; SAM). CDD trends only are for SAM dry season (JJA). Trend values are in $\% \cdot \mathrm{yr}^{-1}$. Significant trends are shown in bold.

\begin{tabular}{lll}
\hline Index & NAM (Feb-Jun) & SAM (Nov-Mar) \\
\hline R20mm & $\mathbf{3 . 7} \pm \mathbf{2 . 8}$ & $1.7 \pm 3.0$ \\
R95wp & $0.0 \pm 3.0$ & $1.2 \pm 3.0$ \\
Rx5day & $0.3 \pm 3.0$ & $1.4 \pm 3.0$ \\
ASDII & $-1.9 \pm 3.0$ & $1.7 \pm 3.0$ \\
CWD & $\mathbf{3 . 0} \pm \mathbf{2 . 9}$ & $-1.9 \pm 3.0$ \\
DC & $18.5 \pm 5.2$ & $18.3 \pm 5.4$ \\
COV & $-12.3 \pm 8.9$ & $-15.4 \pm 7.4$ \\
CDD & - & $\mathbf{3 . 7} \pm \mathbf{2 . 8}$ \\
\hline
\end{tabular}

Table 3 Spearman correlation coefficients $(\rho)$ between each index and mean vertically integrated moisture divergence (MVIMD), low level horizontal winds (LLu and LLv), upper level divergence (ULd), and upper level vertical velocity (UL $\omega$ ), for (a) NAM (Feb-Jun) and (b) SAM (Nov-Mar). Correlation coefficients significant at $\mathrm{p} \leq 0.05$ (two-tailed test) are shown in bold.

\begin{tabular}{|c|c|c|c|c|c|}
\hline \multicolumn{6}{|c|}{ (a) NAM (Feb-Jun) } \\
\hline INDEX & VIMFD & $\mathrm{LLu}$ & LLv & ULd & $-\mathrm{UL} \omega$ \\
\hline $\mathrm{R} 20 \mathrm{~mm}$ & -0.73 & 0.50 & -0.13 & -0.55 & 0.05 \\
\hline R95wp & -0.49 & 0.41 & -0.13 & 0.15 & 0.02 \\
\hline Rx5day & 0.27 & 0.20 & 0.05 & -0.11 & -0.09 \\
\hline SSDII & -0.06 & 0.18 & -0.28 & -0.28 & -0.23 \\
\hline CWD & -0.36 & 0.22 & 0.22 & 0.52 & -0.13 \\
\hline $\mathrm{DC}$ & -0.55 & - & - & 0.47 & 0.48 \\
\hline $\mathrm{COV}$ & 0.49 & - & - & -0.04 & 0.0 \\
\hline \multicolumn{6}{|c|}{ (b) SAM (Nov-Mar) } \\
\hline INDEX & VIMFC & $\mathrm{LLu}$ & LLv & ULd & $-\mathrm{UL} \omega$ \\
\hline $\mathrm{R} 20 \mathrm{~mm}$ & -0.65 & 0.22 & -0.03 & 0.58 & 0.51 \\
\hline R95wp & -0.58 & 0.05 & -0.18 & 0.45 & 0.48 \\
\hline Rx5day & -0.49 & 0.01 & -0.18 & 0.36 & 0.39 \\
\hline SSDII & -0.52 & 0.05 & -0.20 & 0.39 & 0.44 \\
\hline CWD & -0.49 & 0.61 & 0.53 & 0.61 & 0.54 \\
\hline $\mathrm{DC}$ & -0.57 & - & - & 0.56 & 0.51 \\
\hline $\mathrm{COV}$ & 0.39 & - & - & -0.33 & -0.47 \\
\hline CDD (Jun-Aug) & 0.63 & -0.49 & 0.22 & -0.42 & -0.24 \\
\hline
\end{tabular}

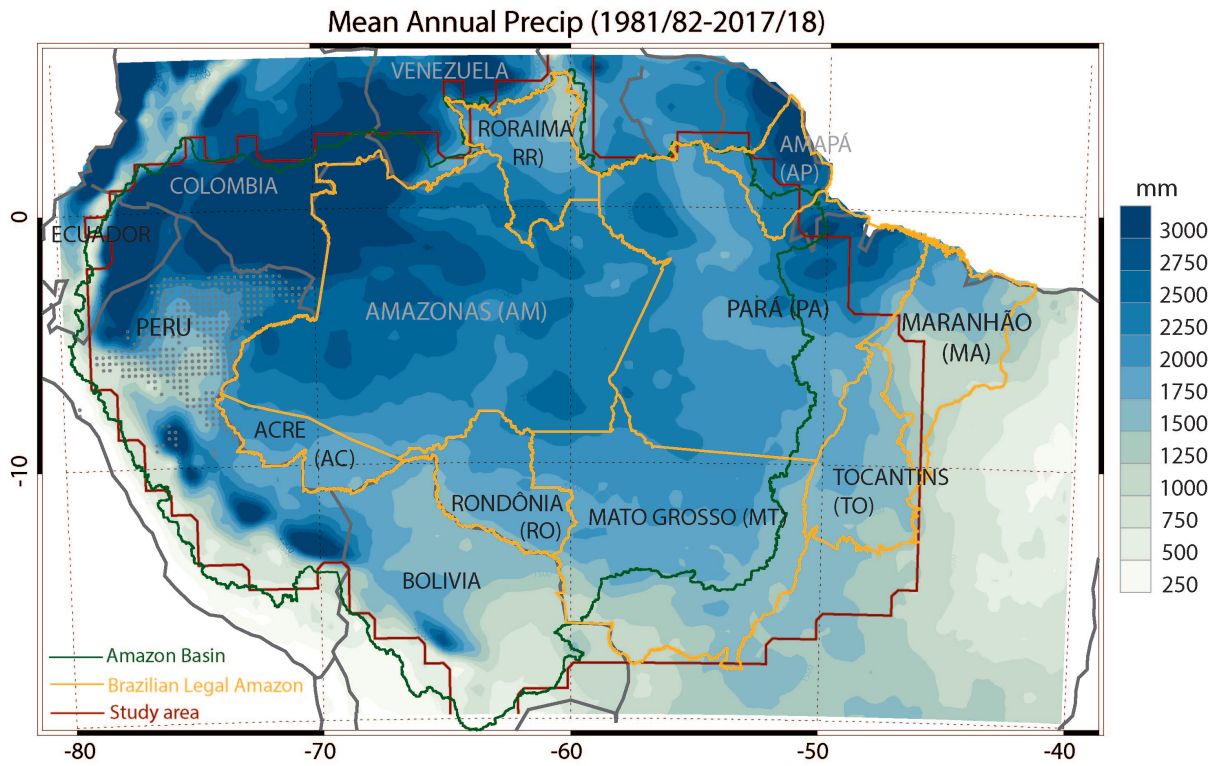

Fig. 1 Mean annual precipitation for the period 1981/82 - 2017/18 based on CHIRPS data. The area of study is delimited by the dark red contour, the Brazilian Legal Amazon states are shown in yellow, and the limits of the Amazon Basin in dark green. 


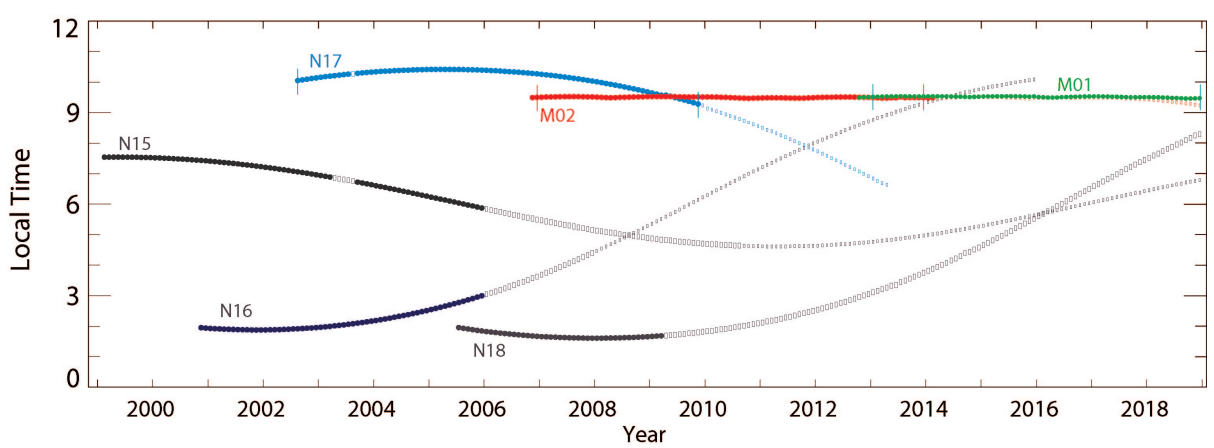

Fig. 2 Equatorial crossing time (local time) for the ascending (afternoon)/descending (morning) nodes of NOAA and MetOp platforms for the period 1999-2019 (source: http://www.ospo.noaa.gov/Products/ppp/navpage.html). Open symbols denote periods where problems with AMSU-B or MHS were reported (see Funatsu et al. (2018) and https://www.wmo-sat.info/oscar/satellites for extended information); small open symbols denote AMSU-B/MHS instrument failure. Only NOAA-17 (N17), MetOp-A (M02), and MetOp-B (M01), which have closer local sampling hours, are used in this study. 

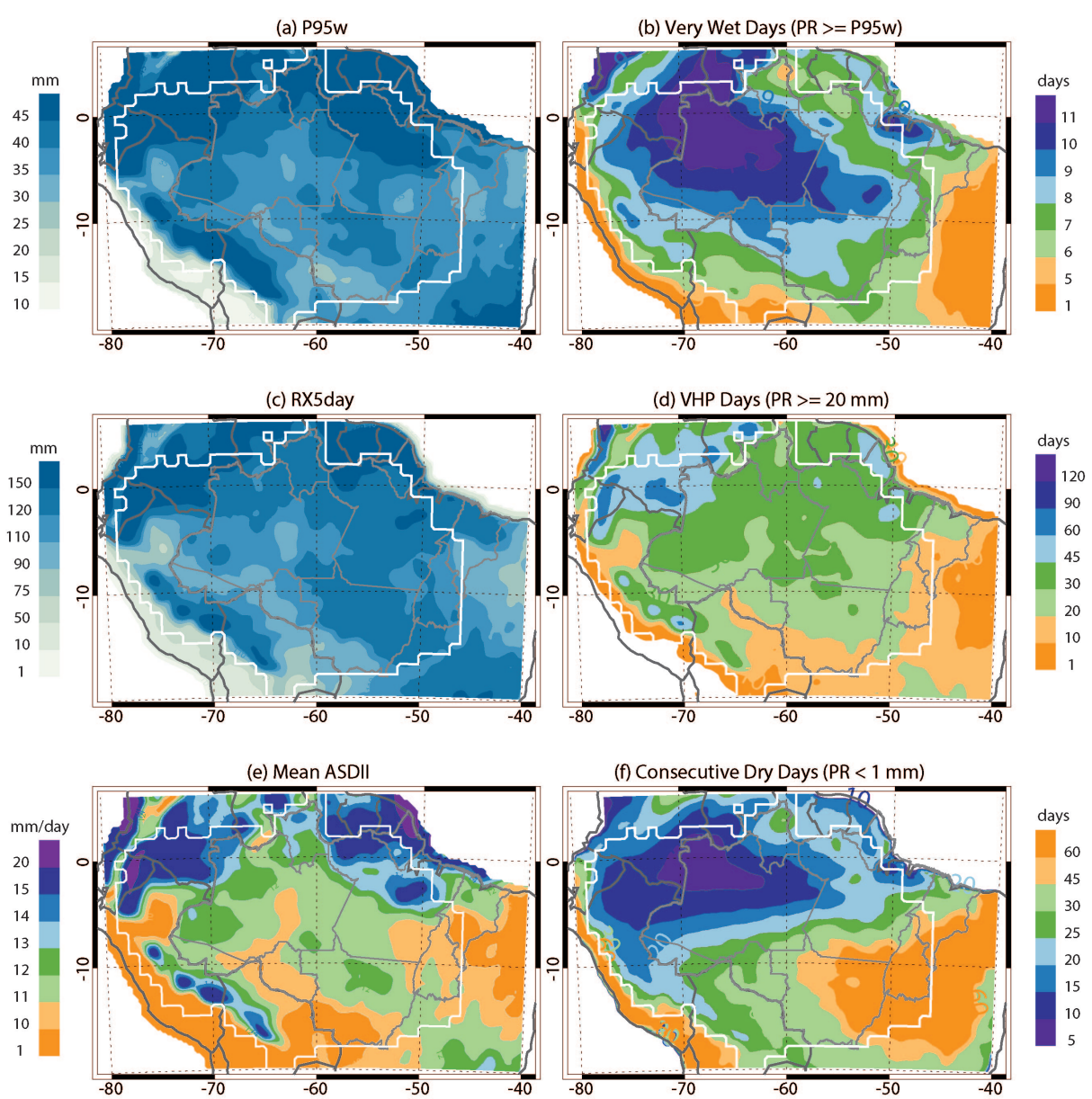

Fig. 3 Spatial distribution of 37-year (1981/82-2017/18) mean (a) P95w (mm), (b) R95w (days), (c) RX5day (mm), (d) R20mm (days), (e) ASDII (mm.day ${ }^{-1}$ ), and (f) CDD (days)). White line shows the study domain. A boxcar smoothing filter with a width=5 was used for plotting. 

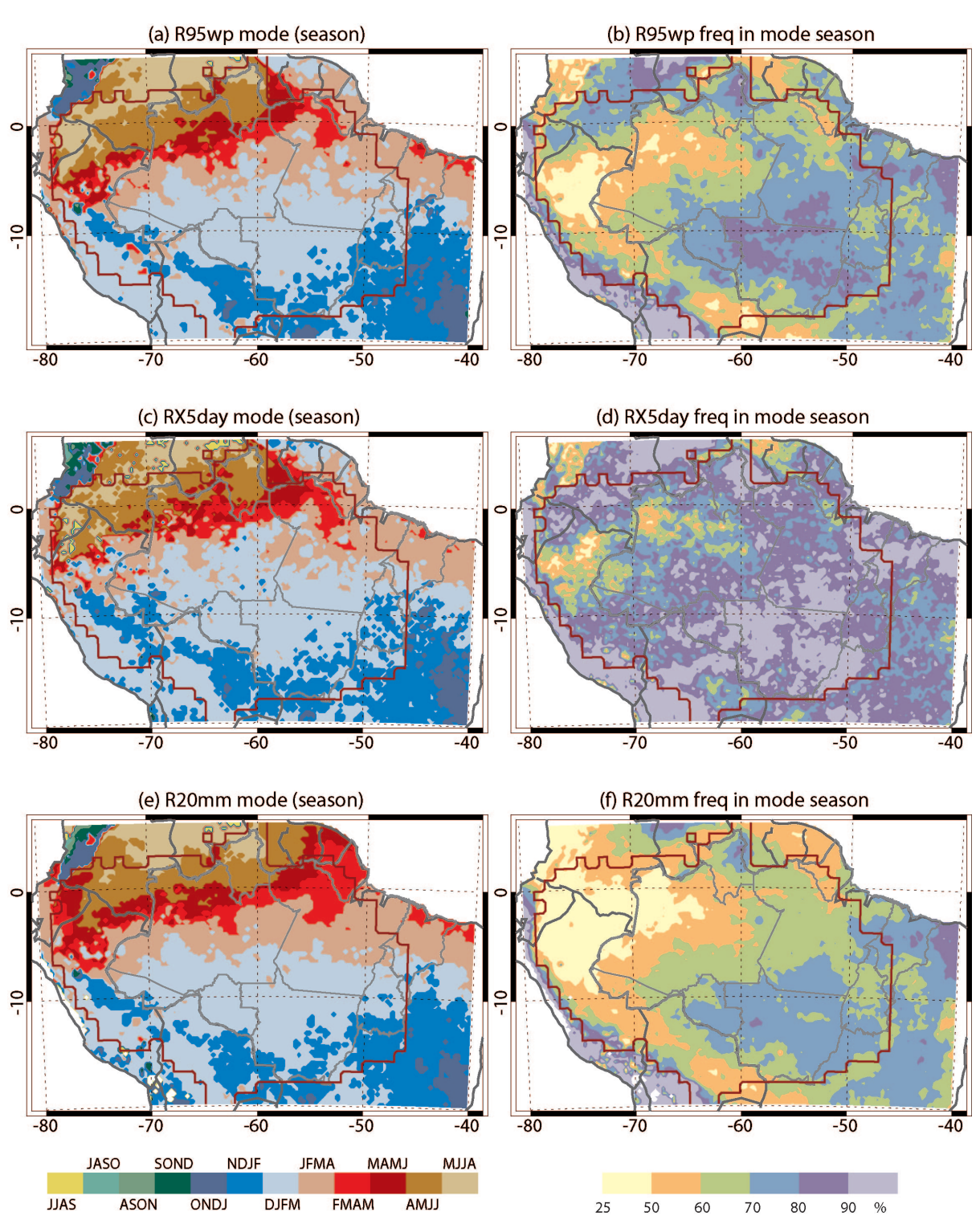

Fig. 4 Spatial distribution of months of most frequent occurrence (that is, the statistical mode) of (a) R95wp, (c) RX5day, and (e) R20mm, and the relative proportion of occurrence in the mode months, respectively, in (b), (d) and (f). 

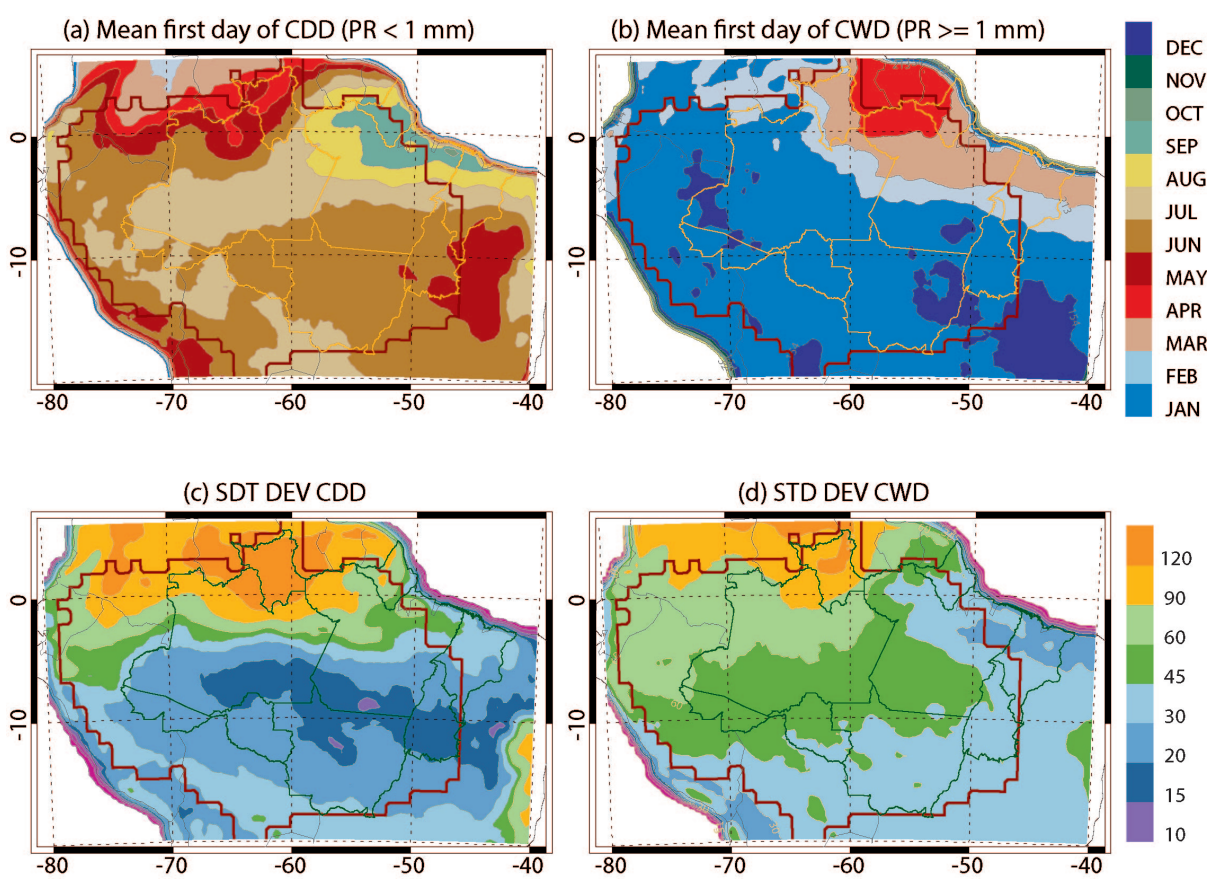

Fig. 5 Spatial distribution of 37-year (1981-2018) mean (a) month in which CDD period starts, (b) same as in (a) but for CWD, (c) standard deviation of starting CDD date, (d) same as in (c) but for CWD. A boxcar smoothing filter with a width $=5$ was used for plotting.
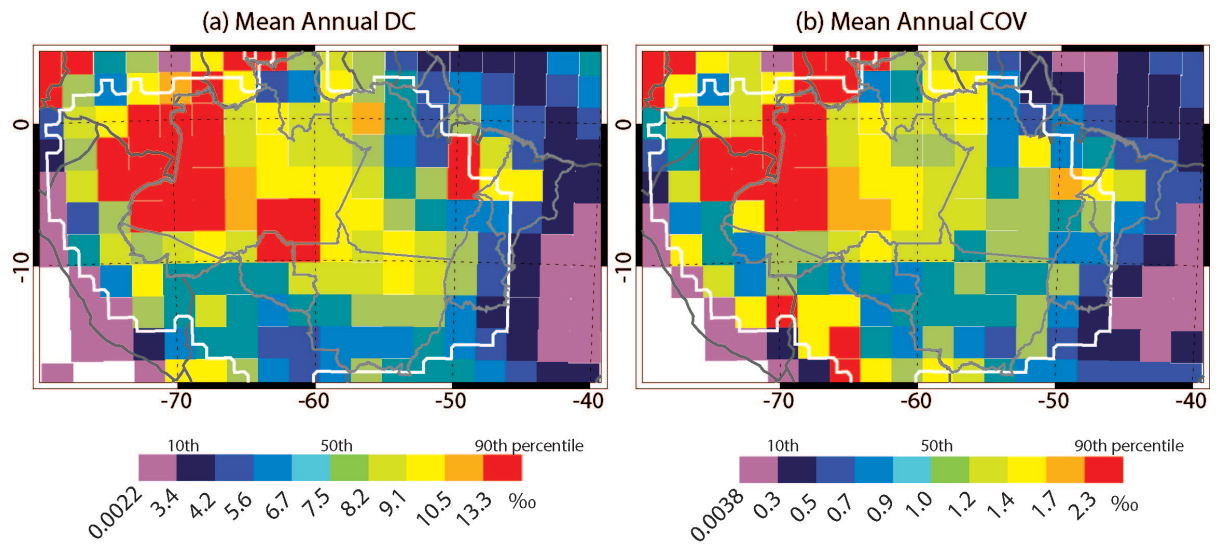

Fig. 6 Mean (2002-2018) annual frequency of (a) Deep convective clouds (DC), and (b) convective overshooting clouds (COV), based on N17, M02 and M01 MHS data. The colour scale classes were fixed according to the DC ou COV percentile rank, from the 10th to the 90th percentile. 

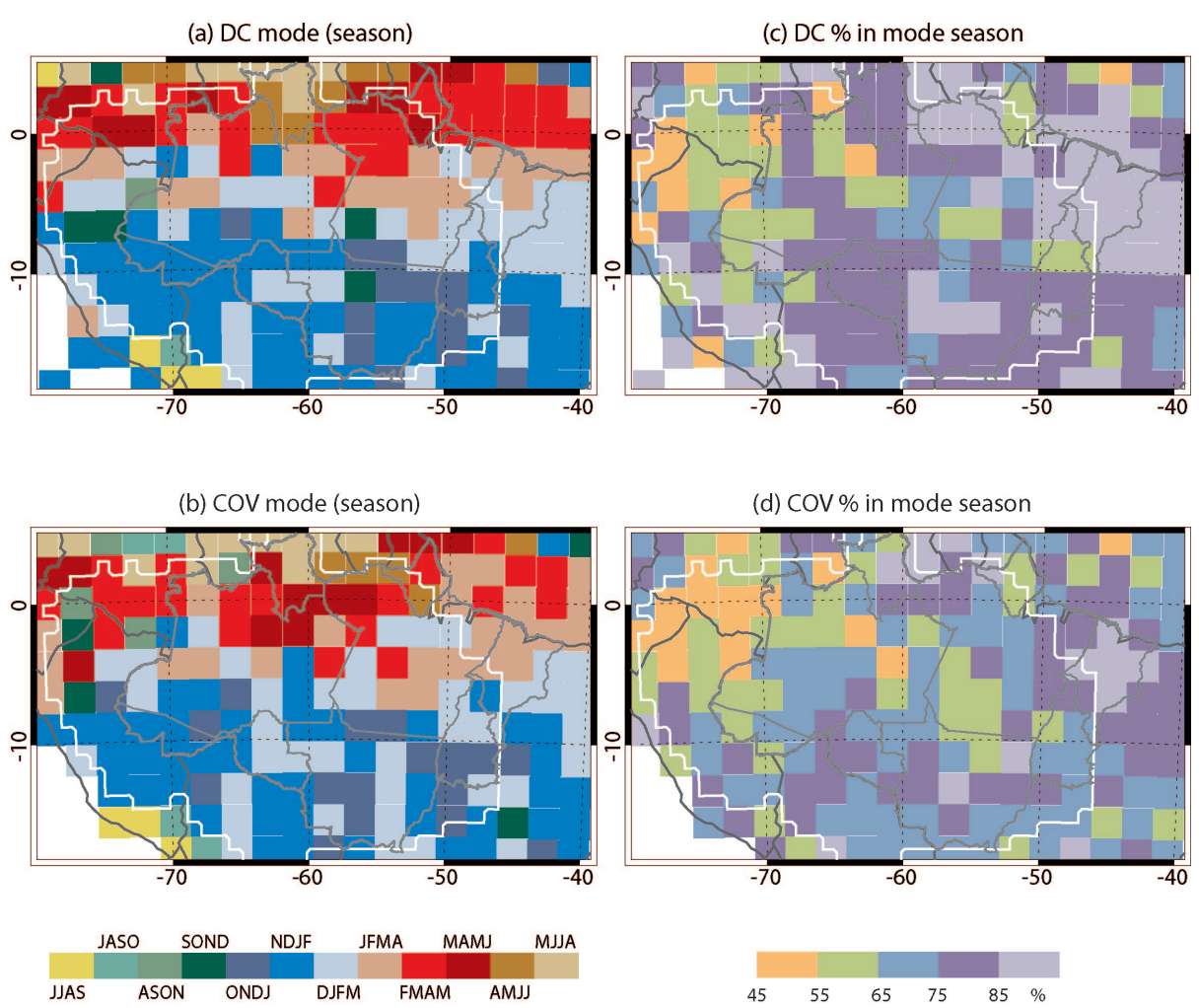

Fig. 7 Spatial distribution of months of most frequent occurrence (that is, the statistical mode) of (a) DC, (c) COV, and the relative proportion of occurrence in the mode month, respectively, in (b), (d). 
(a) Monthly Mean Stdzed COV [5S-2N, 75-50W]

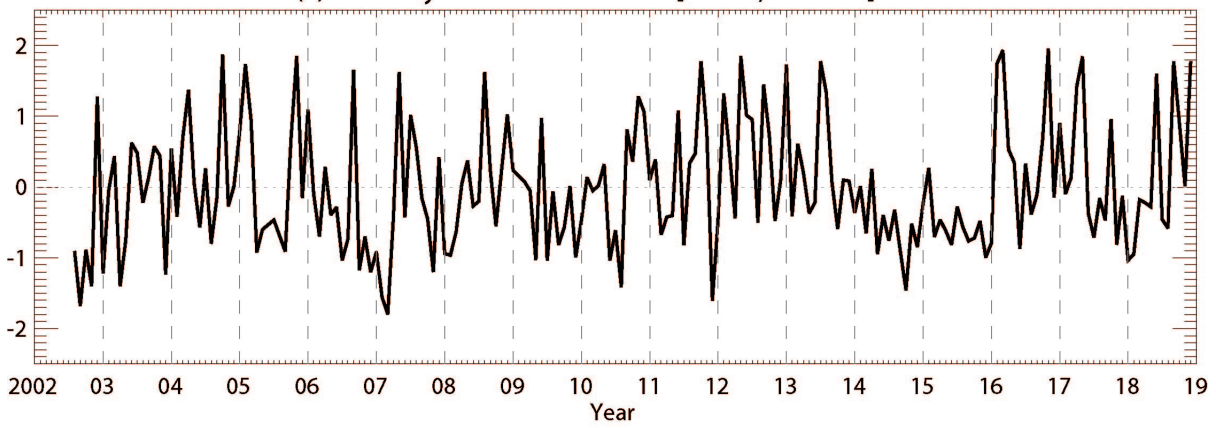

(b) Monthly Mean Stdzed COV [18-10S, 68-50W]

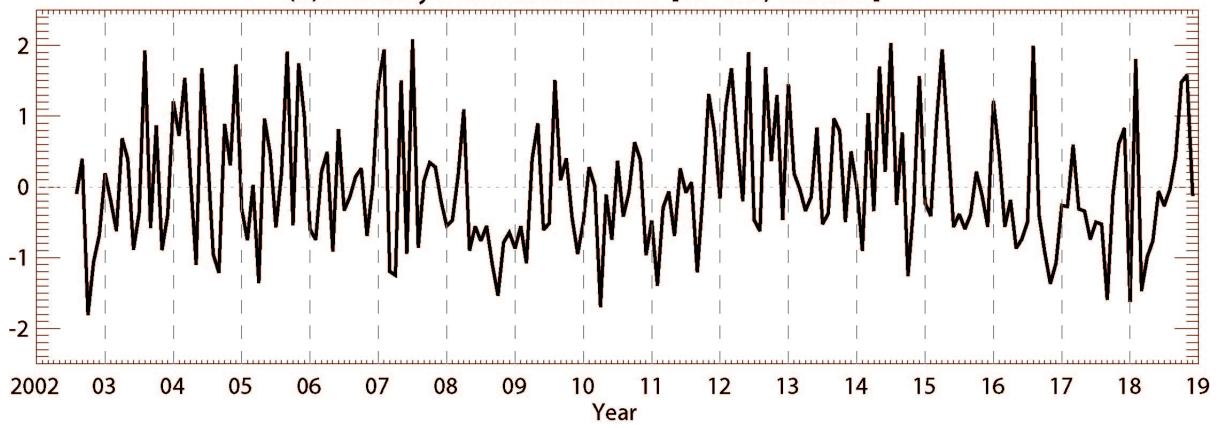

Fig. 8 Time series of standardized COV for (a) Northern and (b) Southern Amazon region (2002-2009 for N17, 2007-2013 for MetOp-A, and 2013-2018 for MetOp B). 

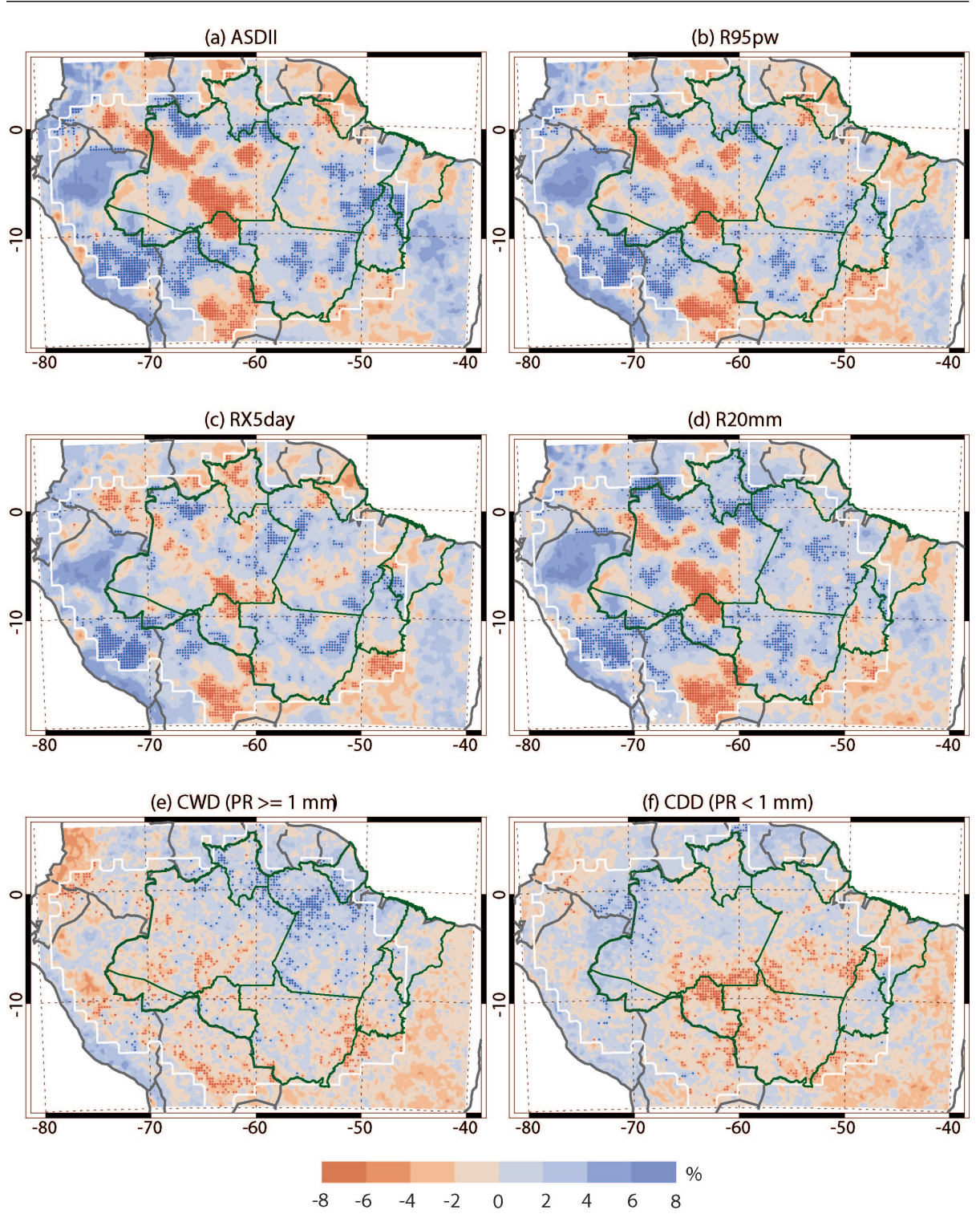

Fig. 9 Linear trends coefficients for standardized series of (a) ASDII (mm.day ${ }^{-1} \cdot \mathrm{yr}^{-1}$, (b) R95wp (days.yr $\left.{ }^{-1}\right)$, (c) RX5day $\left(\mathrm{mm}_{\mathrm{yr}} \mathrm{y}^{-1}\right)$, (d) R20mm (days.yr ${ }^{-1}$ ), (e) CWD (days.yr ${ }^{-1}$ ), and (f) CDD (days.yr ${ }^{-1}$ ). The color scale for CDD is inverted, so that hues in red (blue) denote increasing (decreasing) CDD anomalies. Values above $95 \%$ confidence interval are marked with dark dots. 

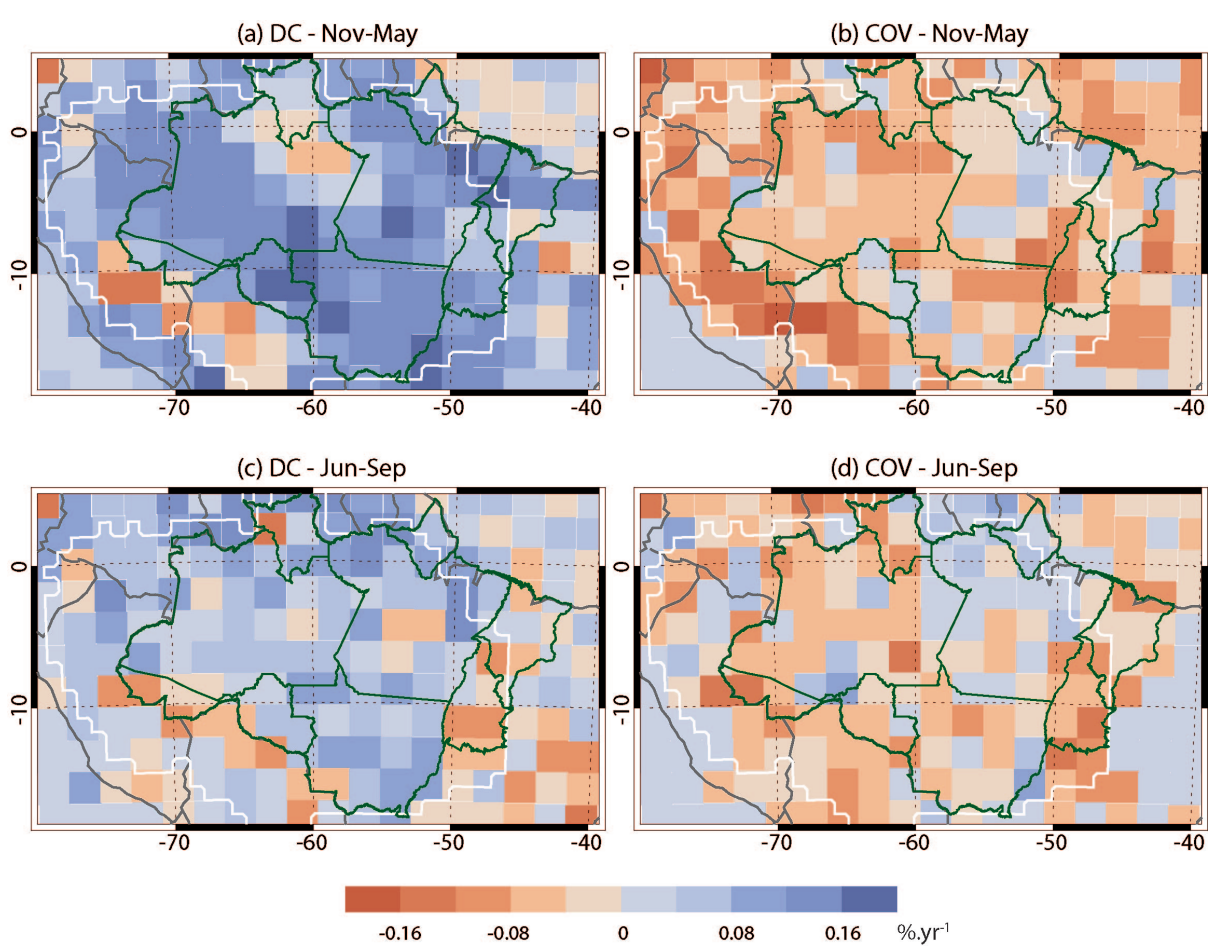

Fig. 10 Linear trends coefficients (\%.yr-1) for normalized series of (a) DC, (b) COV, averaged over November-May, and (c) DC, (d) COV, averaged over June-September. 


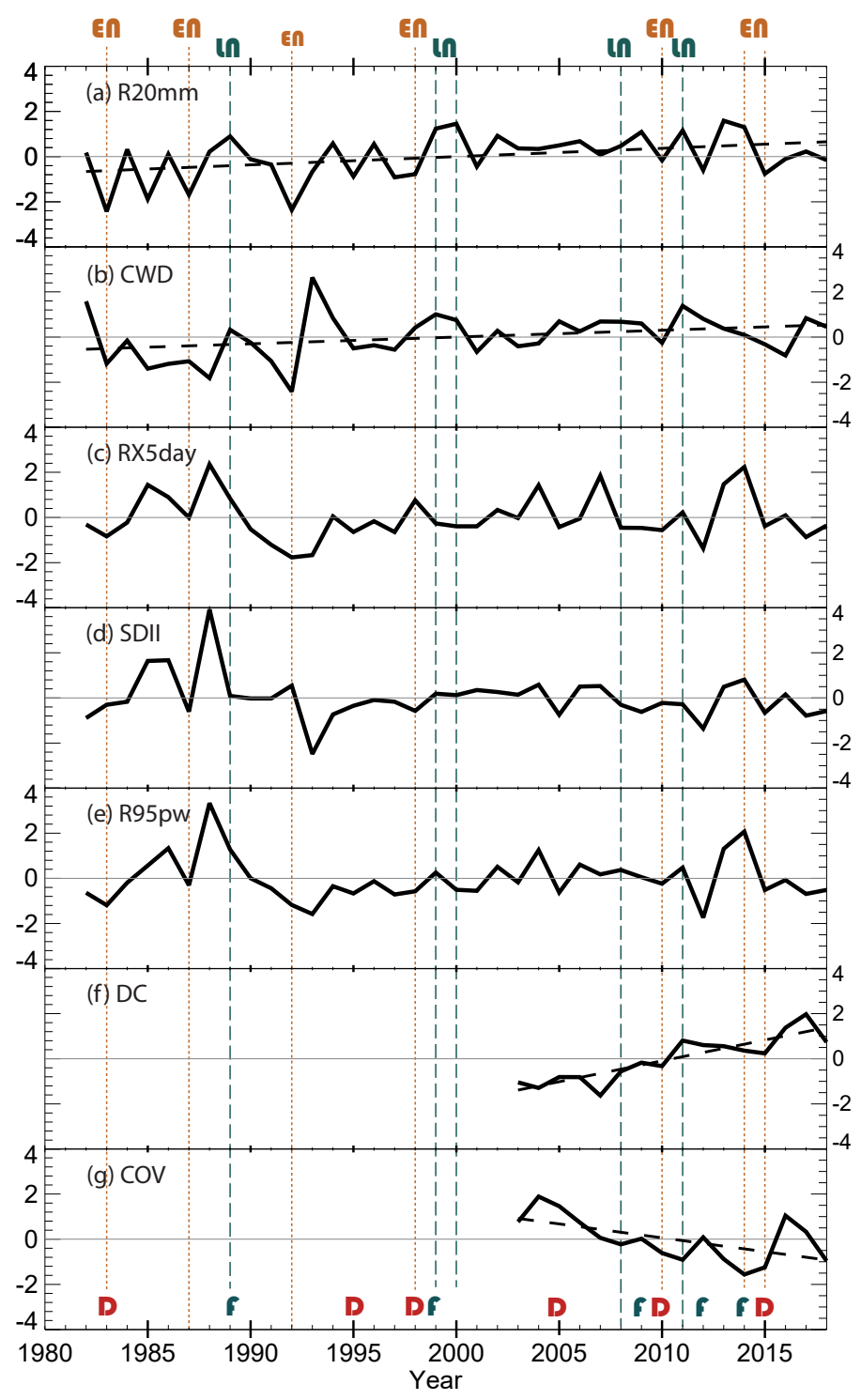

Fig. 11 Time series of mean seasonal (February to June) normalized indices averaged over northern Amazon (north of $5^{\circ} \mathrm{S}$ ): (a) R20mm, (b) CWD, (c) RX5day, (d) SDII, (e) R95wp, (f) $\mathrm{DC}$, and $(\mathrm{g}) \mathrm{COV}$. Dashed lines denote the linear regression for statistically significant trends (above 95\% confidence interval). Years of El Niño and La Niña are are marked as, respectively, EN and LN, and drought and flood years are marked as D and F, respectively. 


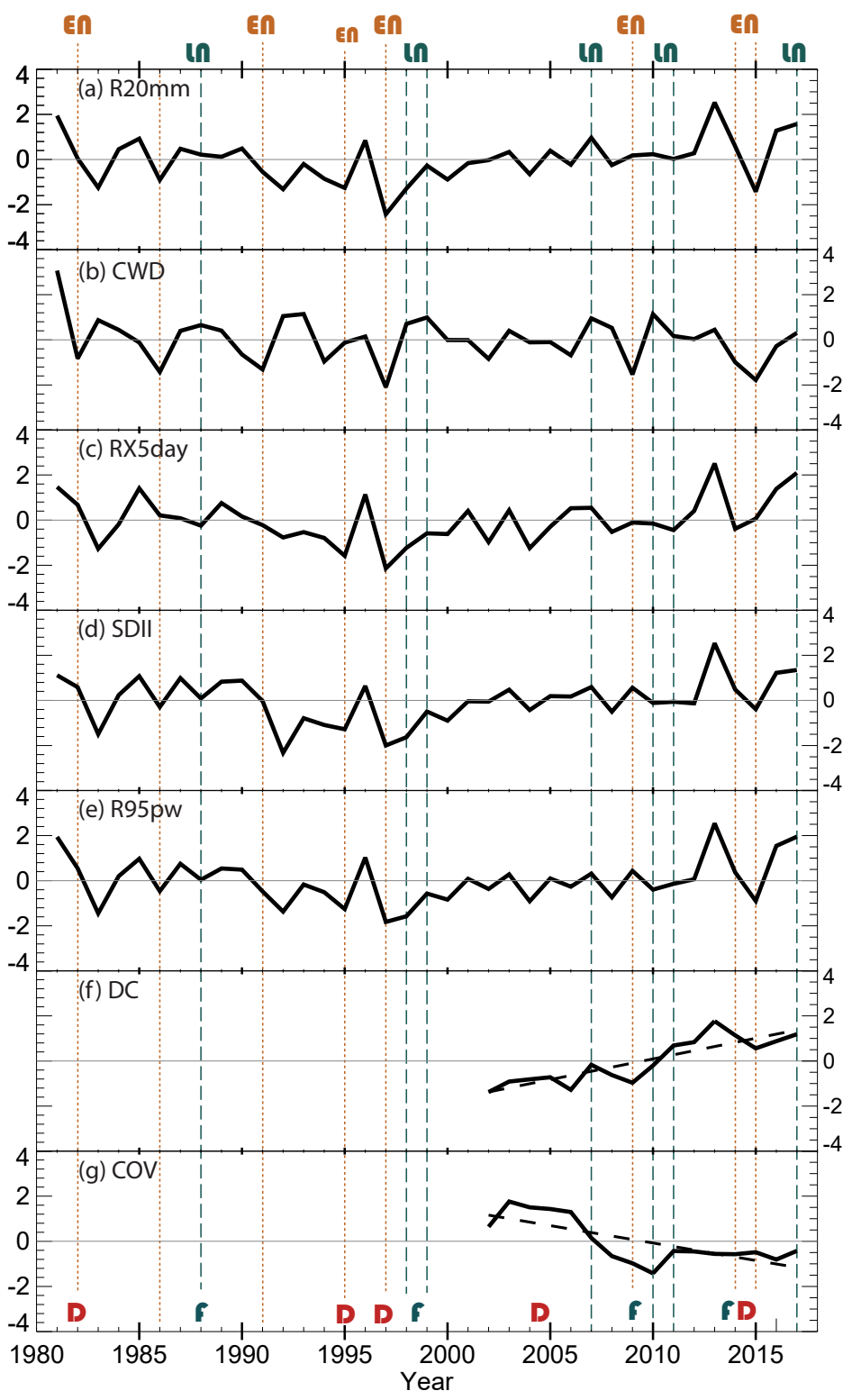

Fig. 12 Time series of mean seasonal (November to March) normalized indices averaged over southern Amazon (south of $5^{\circ}$ S): (a) R20mm, (b) CWD, (c) RX5day, (d) SDII, (e) R95wp, (f) DC, and (g) COV. Dashed lines denote the linear regression for statistically significant trends (above $95 \%$ confidence interval). Years of El Niño and La Niña are are marked as, respectively, EN and LN, and drought and flood years are marked as D and F, respectively. Years in the abscissa correspond to that of the months of November and December. 


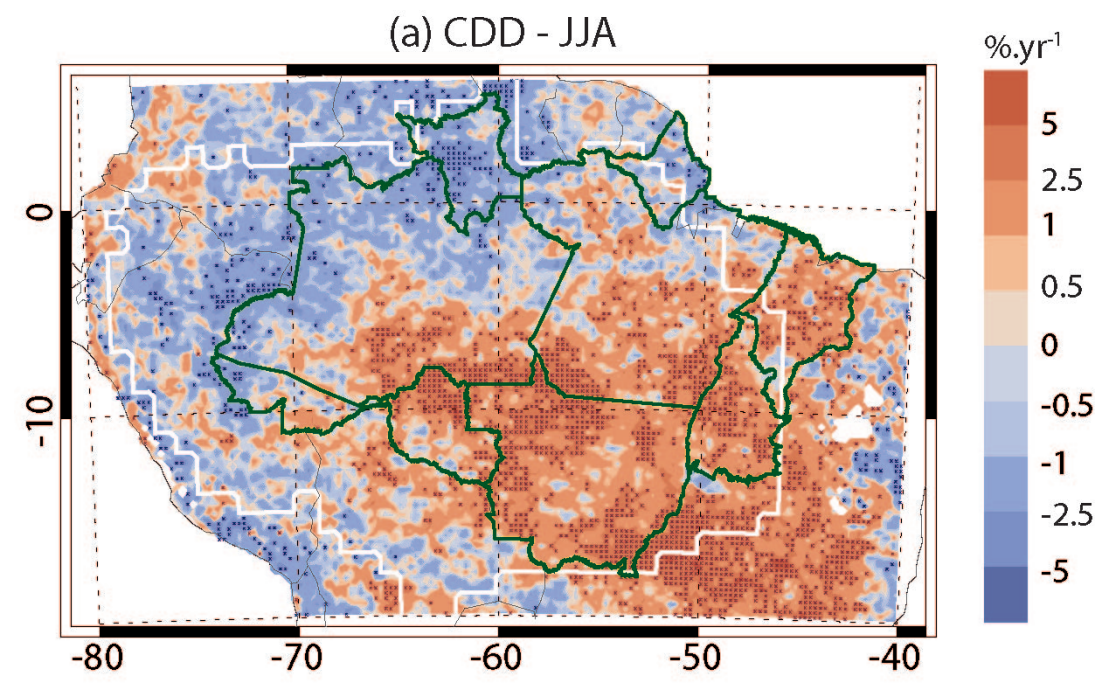

(b) CDD - JJA [south AMZ]

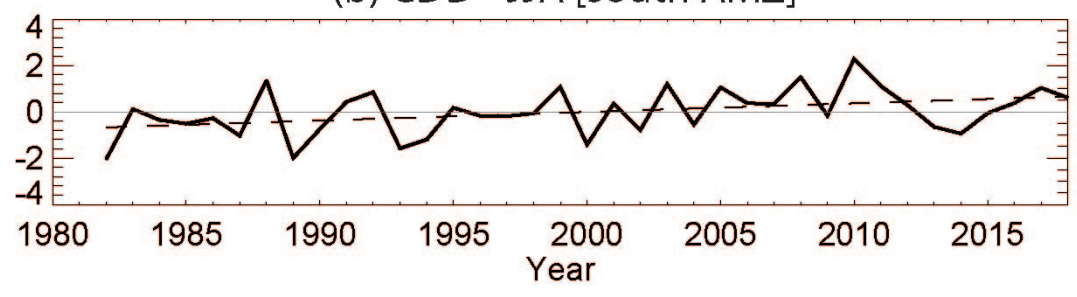

(c) COV - JJA [south AMZ]

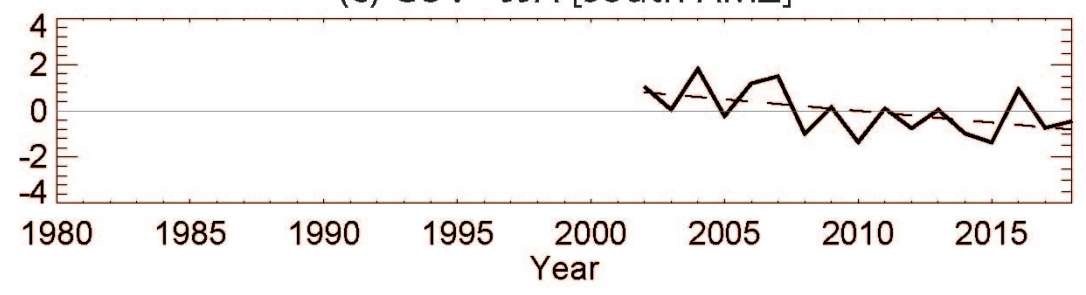

Fig. 13 Dry season (JJA) (a) linear regression coefficients (\%.yr $\mathrm{r}^{-1}$ ) of CDD, with darker points for grid points where trend coefficients are significant at 95\%, (b) CDD time series averaged over southern Amazon (south of $5^{\circ} \mathrm{S}$ ), and (c) same as in (b) but for COV. 


\section{Declarations}

Funding This study was funded by the ODYSSEA project (European Union's Horizon 2020 Research and innovation programme Marie Skłodowska Curie No 691053), and by the French National Centre for Scientific Research (CNRS) International Emerging Action project SCOLTEL. BMF and CC acknowledge the CNRS-LEFE project "Parashoots". JCE is supported by the French AMANECERMOPGA project funded by ANR and IRD (ref. ANR-18-MPGA-0008).

Conflicts of interest/Competing interests The authors declare no conflicts of interest.

Availability of data and material CHIRPS v2 is available at https://www.chc.ucsb.edu/data/chirps. AMSU data is available through the Comprehensive Large Array-data Stewardship System (CLASS; https://www.class.noaa.gov)

Code availability All codes used in this study were developed by B.M.F. Software to process and anlayse precipitation extremes are made freely available by the ETCCDI team, at http://etccdi.pacificclimate.org/software.shtml

\section{References}

Alexander LV, Zhang X, Peterson TC, Caesar J, Gleason B, Klein Tank AMG, Haylock M, Collins D, Trewin B, Rahimzadeh F, Tagipour A, Rupa Kumar K, Revadekar J, Griffiths G, Vincent L, Stephenson DB, Burn J, Aguilar E, Brunet M, Taylor M, New M, Zhai P, Rusticucci M, Vazquez-Aguirre JL (2006) Global observed changes in daily climate extremes of temperature and precipitation. J Geophys Res Atmos 111(D5), DOI 10.1029/2005JD006290

Ambrizzi T, Ferraz SET (2015) An objective criterion for determining the South Atlantic Convergence Zone. Frontiers in Environmental Science 3:23, DOI 10.3389/fenvs.2015.00023

Andreoli RV, Ferreira de Souza RA, Kayano MT, Candido LA (2012) Seasonal anomalous rainfall in the central and eastern Amazon and associated anomalous oceanic and atmospheric patterns. Int J Climatol 32(8):1193-1205, DOI $10.1002 /$ joc. 2345

Arias P, Fu R, Vera C, Rojas M (2015) A correlated shortening of the North and South American monsoon seasons in the past few decades. Climate Dyn 45:3183-3203, DOI 10.1007/s00382-015-2533-1

Arvor D, Meirelles M, Dubreuil V, Bégué A, Shimabukuro YE (2012) Analyzing the agricultural transition in Mato Grosso, Brazil, using satellite-derived indices. Appl Geography 32(2):702-713

Arvor D, Dubreuil V, Ronchail J, Simões M, Funatsu B (2014) Spatial patterns of rainfall regimes related to levels of double cropping agriculture systems in Mato Grosso (Brazil). Int J Climatol 34:2622-2633, DOI 10.1002/joc.3863

Arvor D, Funatsu BM, Michot V, Dubreuil V (2017) Monitoring rainfall patterns in the Southern Amazon with PERSIANN-CDR data: Long-term characteristics and trends. Remote Sensing 9:889, DOI 10.3390/rs9090889

Arvor D, Daher F, Briand D, Dufour S, Rollet AJ, Simões M, Ferraz R (2018) Monitoring thirty years of small water reservoirs proliferation in the southern Brazilian Amazon with Landsat time series. ISPRS J Photogramm Remote Sens 145, DOI 10.1016/j.isprsjprs.2018.03.015 
Bagley JE, Desai AR, Harding K, Snyder PK, Foley JA (2013) Drought and deforestation: Has land cover change influenced recent precipitation extremes in the Amazon? J Climate 27:345-361, DOI 10.1175/CLI-D-12-00369.1

Baker JCA, Spracklen DV (2019) Climate benefits of intact Amazon forests and the biophysical consequences of disturbance. Frontiers in Forests and Global Change 2:47, DOI 10.3389/ffgc.2019.00047

Barichivich J, Gloor E, Peylin P, Brienen RJW, Schöngart J, Espinoza JC, Pattnayak KC (2018) Recent intensification of Amazon flooding extremes driven by strengthened Walker circulation. Science advances 4(9):eaat8785, DOI 10.1126/sciadv.aat8785

Boisier JP, Ciais P, Ducharne A, Guimberteau M (2015) Projected strengthening of Amazonian dry season by constrained climate model simulations. Nat Clim Change 5:656-660, DOI 10.1038/nclimate2658

Caioni C, Silvério DV, Macedo MN, Coe MT, Brando PM (2020) Droughts amplify differences between the energy balance components of Amazon forests and croplands. Remote Sensing 12(3), DOI 10.3390/rs12030525

Callède J, Guyot JL, Ronchail J, L'Hôte Y, Niel H, de Oliveira E (2004) Evolution du débit de l'Amazone à Óbidos de 1903 à 1999 / Evolution of the River Amazon's discharge at Óbidos from 1903 to 1999. Hydrological Sciences Journal 49(1):85-97, DOI 10.1623/hysj.49.1.85.53992

Carvalho LMV, Jones C, Liebmann B (2004) The South Atlantic Convergence Zone: Intensity, form, persistence, and relationships with intraseasonal to interannual activity and extreme rainfall. J Climate 17(1):88-108, DOI 10.1175/15200442(2004)017;0088:TSACZI ¿2.0.CO;2

Carvalho LMV, Jones C, Silva AE, Liebmann B, Silva Dias PL (2011) The South American Monsoon System and the 1970s climate transition. Int J Climatol 31(8):1248-1256, DOI https://doi.org/10.1002/joc.2147

Cavalcante RBL, da Silva Ferreira DB, Pontes PRM, Tedeschi RG, da Costa CPW, de Souza EB (2020) Evaluation of extreme rainfall indices from CHIRPS precipitation estimates over the Brazilian Amazonia. Atmos Res 238:104879, DOI $10.1016 /$ j.atmosres.2020.104879

Chavez SP, Takahashi K (2017) Orographic rainfall hot spots in the Andes-Amazon transition according to the TRMM precipitation radar and in situ data. J Geophys Res Atmos 122(11):5870-5882, DOI 10.1002/2016JD026282

Claud C, Alhammoud B, Funatsu BM, Lebeaupin Brossier C, Chaboureau JP, Béranger K, Drobinski P (2012) A high resolution climatology of precipitation and deep convection over the Mediterranean region from operational satellite microwave data: development and application to the evaluation of model uncertainties. Nat Hazards Earth Syst Sci 12(3):785-798, DOI 10.5194/nhess-12-7852012

Correia F, Alvalá R, Manzi AO (2008) Modeling the impacts of land cover change in Amazonia: a regional climate model (RCM) simulation study. Theor Appl Climatol 93:225-244, DOI 10.1007/s00704-007-0335-z

Cotrim MF, Gava R, Campos CNS, de David CHO, Reis IdA, Teodoro LPR, Teodoro PE (2020) Physiological performance of soybean genotypes grown under irrigated and rainfed conditions. Journal of Agronomy and Crop Science n/a(n/a), DOI 10.1111/jac.12448

Cox PM, Harris PP, Huntingford C, Betts RA, Collins M, Jones CD, Jupp TE, Marengo JA, , Nobre CA (2008) Increasing risk of Amazonian drought due to 
decreasing aerosol pollution. Nature 453:212-215, DOI 10.1038/nature06960

Debortoli NS, Dubreuil V, Funatsu B, Delahaye F, de Oliveira CH, RodriguesFilho S, Saito CH, Fetter R (2015) Rainfall patterns in the Southern Amazon: a chronological perspective (1971-2010). Climatic Change 132:251-264, DOI 10.1007/s10584-015-1415-1

Debortoli NS, Dubreuil V, Hirota M, Filho SR, Lindoso DP, Nabucet J (2017) Detecting deforestation impacts in Southern Amazonia rainfall using rain gauges. Int J Climatol 37(6):2889-2900, DOI 10.1002/joc.4886

Dubreuil V, Debortoli N, Funatsu BM, edélec VN, Durieux L (2012) Impact of land-cover change in the Southern Amazonia Climate: A case study for the region of Alta Floresta, Mato Grosso, Brazil. Environmental Monitoring and Assessment 184:877-891, DOI 10.1007/s10661-011-2006-x

Dubreuil V, Fante KP, Planchon O, Sant'Anna Neto JL (2019) Climate change evidence in Brazil from Köppen's climate annual types frequency. Int J Climatol 39(3):1446-1456, DOI 10.1002/joc.5893

Dubreuil V, Arvor D, Funatsu BM, Nédélec V, Mello-Théry NAd (2020) Les changements climatiques en Amazonie, une approche multiscalaire. In: Mercier D (ed) Les impacts spatiaux du changement climatique, ISTE, pp 247-270

Espinoza JC, Chavez S, Ronchail J, Junquas C, Takahashi K, Lavado W (2015) Rainfall hotspots over the southern tropical Andes: Spatial distribution, rainfall intensity, and relations with large-scale atmospheric circulation. Water Resources Research 51(5):3459-3475, DOI 10.1002/2014WR016273

Espinoza JC, Ronchail J, Marengo JA, Segura H (2019a) Contrasting north-south changes in Amazon wet-day and dry-day frequency and related atmospheric features (1981-2017). Climate Dyn 52:5413-5430, DOI 10.1007/s00382-018-4462-2

Espinoza JC, Sörensson AA, Ronchail J, Molina-Carpio J, Segura H, GutierrezCori O, Ruscica R, Condom T, Wongchuig-Correa S (2019b) Regional hydroclimatic changes in the Southern Amazon Basin (Upper Madeira Basin) during the 1982-2017 period. Journal of Hydrology: Regional Studies 26:100637, DOI 10.1016/j.ejrh.2019.100637

Espinoza JC, Garreaud R, Poveda G, Arias PA, Molina-Carpio J, Masiokas M, Viale M, Scaff L (2020) Hydroclimate of the Andes Part I: Main climatic features. Frontiers in Earth Science 8:64, DOI 10.3389/feart.2020.00064

Espinoza Villar JC, Ronchail J, Guyot JL, Cochonneau G, Naziano F, Lavado W, De Oliveira E, Pombosa R, Vauchel P (2009) Spatio-temporal rainfall variability in the Amazon basin countries (Brazil, Peru, Bolivia, Colombia, and Ecuador). Int J Climatol 29(11):1574-1594, DOI 10.1002/joc.1791

Fernandes K, Giannini A, Verchot L, Baethgen W, Pinedo-Vasquez M (2015) Decadal covariability of Atlantic SSTs and western Amazon dry-season hydroclimate in observations and CMIP5 simulations. Geophys Res Lett 42(16):67936801, DOI 10.1002/2015GL063911

Fischer EM, Sedlácek J, Hawkins E, Knutti R (2014) Models agree on forced response pattern of precipitation and temperature extremes. Geophys Res Lett 41(23):8554-8562, DOI 10.1002/2014GL062018

Fu R, Yin L, Li W, Arias PA, Dickinson RE, Huang L, Chakraborty S, Fernandes K, Liebmann B, Fisher R, Myneni RB (2013) Increased dry-season length over southern Amazonia in recent decades and its implication for future climate projections. Proc Natl Acad Sci (USA) 110(45):18110-18115, DOI $10.1073 /$ pnas. 1302584110 
Funatsu BM, Claud C, Chaboureau JP (2009) Comparison between the large-scale environments of moderate and intense precipitating systems in the Mediterranean region. Mon Wea Rev 137(11):3933-3959, DOI 10.1175/2009MWR2922.1

Funatsu BM, Dubreuil V, Claud C, Arvor D, Gan MA (2012) Convective activity in Mato Grosso state (Brazil) from microwave satellite observations: Comparisons between AMSU and TRMM data sets. J Geophys Res Atmos 117(D16), DOI 10.1029/2011JD017259

Funatsu BM, Rysman JF, Claud C, Chaboureau JP (2018) Deep convective clouds distribution over the Mediterranean region from AMSU-B/MHS observations. Atmos Res 207:122 - 135, DOI 10.1016/j.atmosres.2018.03.003

Funatsu BM, Dubreuil V, Racapé A, Debortoli NS, Nasuti S, Le Tourneau FM (2019) Perceptions of climate and climate change by Amazonian communities. Global Environmental Change 57:101923, DOI 10.1016/j.gloenvcha.2019.05.007

Funk C, Peterson P, Pedreros D, Verdin J, Shukla S, Husak G, Rowland J, Harrison L, Howell A, Michaelsen J (2015) The Climate Hazards infrared precipitation with stations - new environmental record for monitoring extremes. Scientific Data 2:150066, DOI 10.1038/sdata.2015.66

Gan MA, Kousky VE, Ropelewski CF (2004) The South America monsoon circulation and its relationship to rainfall over west-central Brazil. J Climate 17(1):4766, DOI 10.1175/1520-0442(2004)017<0047:TSAMCA > 2.0.CO;2

Gloor M, Brienen RJW, Galbraith D, Feldpausch TR, Schöngart J, Guyot JL, Espinoza JC, Lloyd J, Phillips OL (2013) Intensification of the Amazon hydrological cycle over the last two decades. Geophys Res Lett 40:1729-1733, DOI $10.1002 /$ grl.50377

Gloor M, Barichivich J, Ziv G, Brienen R, Schöngart J, Peylin P, Ladvocat Cintra BB, Feldpausch T, Phillips O, Baker J (2015) Recent Amazon climate as background for possible ongoing and future changes of Amazon humid forests. Global Biogeochemical Cycles 29(9):1384-1399, DOI 10.1002/2014GB005080

Haghtalab N, Moore N, Heerspink B, Hyndman DW (2020) Evaluating spatial patterns in precipitation trends across the Amazon basin driven by land cover and global scale forcings. Theor Appl Climatol 140:411-427, DOI 10.1007/s00704019-03085-3

Hampf AC, Stella T, Berg-Mohnicke M, Kawohl T, Kilian M, Nendel C (2020) Future yields of double-cropping systems in the Southern Amazon, Brazil, under climate change and technological development. Agricultural Systems 177:102707, DOI 10.1016/j.agsy.2019.102707

Hersbach H, Bell B, Berrisford P, Hirahara S, Horányi A, noz-Sabater JM, Nicolas J, Peubey C, Radu R, Schepers D, Simmons A, Soci C, Abdalla S, Abellan X, Balsamo G, Bechtold P, Biavati G, Bidlot J, Bonavita M, Chiara GD, Dahlgren P, Dee D, Diamantakis M, Dragani R, Flemming J, Forbes R, Fuentes M, Geer A, Haimberger L, Healy S, Hogan RJ, Hólm E, Janisková M, Keeley S, Laloyaux P, Lopez P, Lupu C, Radnoti G, de Rosnay P, Rozum I, Vamborg F, Villaume S, Thépaut J (2020) The ERA5 global reanalysis. Quart J Roy Meteor Soc 146:1999-2049, DOI 10.1002/qj.3803

Hong G, Heygster G, Miao J, Kunzi K (2005) Detection of tropical deep convective clouds from AMSU-B water vapor channels measurements. J Geophys Res Atmos 110(D5), DOI 10.1029/2004JD004949

Jacques-Coper M, Garreaud RD (2015) Characterization of the 1970s climate shift in South America. Int J Climatol 35(8):2164-2179, DOI 
https://doi.org/10.1002/joc.4120

Jiménez-Muñoz J, Mattar C, Barichivich J, Santamaría-Artigas A, Takahashi K, Malhi Y, Sobrino JA, van der Schrier G (2016) Record-breaking warming and extreme drought in the Amazon rainforest during the course of El Niño 20152016. Scientific Reports 6:33130, DOI 10.1038/srep33130

Jimenez JC, Libonati R, Peres LF (2018) Droughts Over Amazonia in 2005, 2010, and 2015: A Cloud Cover Perspective. Frontiers in Earth Science 6:227, DOI 10.3389/feart.2018.00227

Jimenez JC, Marengo JA, Alves LM, Sulca JC, Takahashi K, Ferrett S, Collins M (2019) The role of ENSO flavours and TNA on recent droughts over Amazon forests and the Northeast Brazil region. Int J Climatol n/a(n/a), DOI https://doi.org/10.1002/joc.6453

Jones C (2019) Recent changes in the South America low-level jet. npj Clim Atmos Sci 2:20, DOI 10.1038/s41612-019-0077-5

Jones C, Carvalho LMV (2002) Active and break phases in the South American Monsoon System. J Climate 15(8):905-914, DOI 10.1175/15200442(2002)015<0905:AABPIT > 2.0.CO;2

Kayano MT, Andreoli RV (2007) Relations of South American summer rainfall interannual variations with the Pacific Decadal Oscillation. Int J Climatol 27(4):531-540, DOI 10.1002/joc. 1417

Kayano MT, Capistrano VB (2014) How the Atlantic multidecadal oscillation (AMO) modifies the ENSO influence on the South American rainfall. Int J Climatol 34(1):162-178, DOI 10.1002/joc.3674

Kayano MT, Andreoli RV, de Souza RAF (2020) Pacific and Atlantic multidecadal variability relations to the El Niño events and their effects on the South American rainfall. Int J Climatol 40(4):2183-2200, DOI 10.1002/joc.6326

Khanna J, Medvigy D, Fueglistaler S, Walko R (2017) Regional dry-season climate changes due to three decades of Amazonian deforestation. Nature Climate Change 7:200-204, DOI 10.1038/nclimate3226

Kodama Y (1992) Large-scale common features of subtropical precipitation zones (the Baiu Frontal Zone, the SPCZ, and the SACZ) Part I: Characteristics of subtropical frontal zones. J Meteor Soc Japan 70(4):813-836, DOI $10.2151 /$ jmsj1965.70.4_813

Kodama Y (1993) Large-scale common features of sub-tropical convergence zones (the Baiu frontal zone, the SPCZ, and the SACZ) Part II: Conditions of the circulations for generating the STCZs. J Meteor Soc Japan 71(5):581-610, DOI $10.2151 /$ jmsj1965.71.5_581

Lawrence D, Vandecar K (2015) Effects of tropical deforestation on climate and agriculture. Nature Climate Change 5:27-36, DOI 10.1038/nclimate2430

Leite-Filho AT, Costa MH, Fu R (2020) The southern Amazon rainy season: The role of deforestation and its interactions with large-scale mechanisms. Int $\mathrm{J}$ Climatol 40(4):2328-2341, DOI 10.1002/joc.6335

Lenters JD, Cook KH (1997) On the origin of the Bolivian high and related circulation features of the South American climate. J Atmos Sci 54:656-678

Lian T, Chen D, Ying J, Huang P, Tang Y (2018) Tropical Pacific trends under global warming: El Niño-like or La Niña-like? National Science Review 5(6):810812, DOI 10.1093/nsr/nwy134

Marengo J (2004) Interdecadal variability and trends of rainfall across the Amazon basin. Theor Appl Climatol 78:79-96, DOI 10.1007/s00704-004-0045-8 
Marengo JA, Espinoza JC (2016) Review: Extreme seasonal droughts and floods in Amazonia: causes, trends and impacts. Int J Climatol 36:1033-1050, DOI $10.1002 /$ joc. 4420

Marengo JA, Soares WR, Saulo C, Nicolini M (2004) Climatology of the low-level jet east of the andes as derived from the ncep-ncar reanalyses: Characteristics and temporal variability. J Climate 17:2261-2280

Marengo JA, Nobre CA, Tomasella J, Oyama MD, Sampaio de Oliveira G, de Oliveira R, Camargo H, Alves LM, Brown IF (2008) The drought of amazonia in 2005. J Climate 21(3):495-516, DOI 10.1175/2007JCLI1600.1

Marengo JA, Tomasella J, Alves LM, Soares WR, Rodriguez DA (2011) The drought of 2010 in the context of historical droughts in the Amazon region. Geophys Res Lett 38(12), DOI 10.1029/2011GL047436

Marengo JA, Jr CMS, Thonicke K, Burton C, Halladay K, Betts RA, Alves LM, Soares WR (2018) Changes in climate and land use over the Amazon region: Current and future variability and trends. Frontiers in Earth Sciences 6:228, DOI doi:10.3389/feart.2018.00228

Martinez JA, Dominguez F (2014) Sources of atmospheric moisture for the La Plata river basin. J Climate 27(17):6737-6753, DOI 10.1175/JCLI-D-14-00022.1

Mayta VC, Ambrizzi T, Espinoza JC, Silva Dias PL (2018) The role of the Madden-Julian oscillation on the Amazon Basin intraseasonal rainfall variability. Int J Climatol 39(1):343-360, DOI 10.1002/joc.5810

Mayta VC, Silva NP, Ambrizzi T, Silva-Dias P, Espinoza JC (2020) Assessing the skill of all-season diverse Madden-Julian oscillation indices for the intraseasonal Amazon precipitation. Climate Dyn 54:3729-3749, DOI 10.1007/s00382020-05202-9

McGregor S, Timmermann A, Stuecker MF, England MH, Merrifield M, Jin FF, Chikamoto Y (2014) Recent walker circulation strengthening and pacific cooling amplified by atlantic warming. J Climate 27:6737-6753, DOI 10.1175/JCLI-D14-00022.1

Michot V (2017) Spatial and temporal analysis of the precipitation schemes variability in the Amazonian basin. Phd. thesis, Université Rennes 2

Michot V, Vila D, Arvor D, Corpetti T, Ronchail J, Funatsu BM, Dubreuil V (2018) Performance of TRMM TMPA 3B42 V7 in replicating daily rainfall and regional rainfall regimes in the Amazon basin (1998-2013). Remote Sensing 10(12), DOI 10.3390/rs10121879

Nobre CA, Obregón GO, Marengo JA, Fu R, Poveda G (2009) Characteristics of Amazonian Climate: Main Features, American Geophysical Union (AGU), pp 149-162. DOI 10.1029/2009GM000903

Nobre CA, Sampaio G, Borma LS, Castilla-Rubio JC, Silva JS, Cardoso M (2016) Land-use and climate change risks in the Amazon and the need of a novel sustainable development paradigm. Proc Natl Acad Sci (USA) 113(39):1075910768, DOI 10.1073/pnas.1605516113

Nogués-Paegle J, Mo KC (1997) Alternating wet and dry conditions over South America during summer. Mon Wea Rev 125(2):279-291, DOI 10.1175/15200493(1997) $125<0279$ :AWADCO > 2.0.CO;2

de Oliveira Vieira S, Satyamurty P, Andreoli RV (2013) On the South Atlantic Convergence Zone affecting southern Amazonia in austral summer. Atmos Res Lett 14(1):1-6, DOI 10.1002/asl2.401 
Paca VHdM, Espinoza-Dávalos GE, Moreira DM, Comair G (2020) Variability of Trends in Precipitation across the Amazon River Basin Determined from the CHIRPS Precipitation Product and from Station Records. Water 12(5), DOI 10.3390/w12051244

Paccini L, Espinoza JC, Ronchail J, Segura H (2018) Intra-seasonal rainfall variability in the Amazon basin related to large-scale circulation patterns: a focus on western Amazon-Andes transition region. Int J Climatol 38(5):2386-2399, DOI $10.1002 /$ joc. 5341

Paegle JN, Mo KC (2002) Linkages between summer rainfall variability over South America and sea surface temperature anomalies. J Climate 15(12):1389-1407, DOI 10.1175/1520-0442(2002)015<1389:LBSRVO > 2.0.CO;2

Pires GF, Abrahão GM, Brumatti LM, Oliveira LJ, Costa MH, Liddicoat S, Kato E, Ladle RJ (2016) Increased climate risk in Brazilian double cropping agriculture systems: Implications for land use in Northern Brazil. Agricultural and Forest Meteorology 228-229:286 - 298, DOI 10.1016/j.agrformet.2016.07.005

Rao VB, Hada K (1990) Characteristics of rainfall over Brazil: Annual variations and connections with the Southern Oscillation. Theor Appl Climatol 42:81-91, DOI 10.1007/BF00868215

Ronchail J, Gallaire R (2006) ENSO and rainfall along the Zongo valley (Bolivia) from the Altiplano to the Amazon basin. Int J Climatol 26(9):1223-1236, DOI $10.1002 /$ joc. 1296

Ronchail J, Cochonneau G, Molinier M, Guyot J, De Miranda Chaves A, Guimarães V, De Oliveira E (2002) Interannual rainfall variability in the Amazon basin and sea-surface temperatures in the Equatorial Pacific and the tropical Atlantic Oceans. Int J Climatol 22(13):1663 - 1686, DOI 10.1002/joc.815

Ronchail J, Bourrel L, Cochonneau G, Vauchel P, Phillips L, Castro A, Guyot J, De Oliveira E (2005) Inundations in the Mamore basin (South-Western Amazon-Bolivia) and sea-surface temperature in the Pacific and Atlantic oceans. Journal of Hydrology 302(1-4):223-238, DOI 10.1016/j.jhydrol.2004.07.005

Ronchail J, Guyot JL, Espinoza Villar JC, Fraizy P, Cochonneau G, Ordenez JJ (2006) Impact of the Amazon tributaries on major flood in Óbidos. In: Procceedings of the Fifth FRIEND World Conference held at Havana, Cuba, November 2006), IAHS Publ. 308, 2006, 220-225

Rosa EB, Pezzi LP, Quadro MFLd, Brunsell N (2020) Automated detection algorithm for SACZ, oceanic SACZ, and their climatological features. Frontiers in Environmental Science 8:18, DOI 10.3389/fenvs.2020.00018

Rysman JF, Claud C, Chaboureau JP, Delanoë J, Funatsu BM (2016) Severe convection in the Mediterranean from microwave observations and a convectionpermitting model. Quart J Roy Meteor Soc 142:43-55, DOI 10.1002/qj.2611

Sampaio G, Nobre C, Costa MH, Satyamurty P, Soares-Filho BS, Cardoso M (2007) Regional climate change over eastern Amazonia caused by pasture and soybean cropland expansion. Geophys Res Lett 34(17), DOI 10.1029/2007GL030612

Segura H, Espinoza J, Junquas C, Lebel T, Vuille M, Garreaud R (2020) Recent changes in the precipitation-driving processes over the southern tropical Andes/western Amazon. Climate Dyn 54:2613-2631, DOI 10.1007/s00382-02005132-6

Sillmann J, Kharin VV, Zhang X, Zwiers FW, Bronaugh D (2013) Climate extremes indices in the CMIP5 multimodel ensemble: Part1. Model evalu- 
ation in the present climate. J Geophys Res Atmos 118:1716-1733, DOI $10.1002 /$ jgrd.50203

Siqueira JR, Toledo Machado LA (2004) Influence of the frontal systems on the day-to-day convection variability over South America. J Climate 17(9):17541766, DOI 10.1175/1520-0442(2004)017<1754:IOTFSO > 2.0.CO;2

Staal A, Flores BM, Aguiar APD, Bosmans JHC, Fetzer I, Tuinenburg OA (2020) Feedback between drought and deforestation in the Amazon. Environ Res Lett 15:044024, DOI 10.1088/1748-9326/ab738e

Towner J, Cloke HL, Lavado W, Santini W, Bazo J, de Perez EC, Stephens EM (2020) Attribution of Amazon floods to modes of climate variability: A review. Meteorol Appl 27:e1949, DOI 10.1002/met.1949

Vera C, Higgins W, Amador J, Ambrizzi T, Garreaud R, Gochis D, Gutzler D, Lettenmaier D, Marengo J, Mechoso CR, Nogues-Paegle J, Dias PLS, Zhang C (2006) Toward a unified view of the american monsoon systems. J Climate 19(20):4977-5000, DOI 10.1175/JCLI3896.1

Vilanova RS, Delgado RC, da Silva Abel EL, Teodoro PE, Silva Junior CA, Wanderley HS, Capristo-Silva GF (2020) Past and future assessment of vegetation activity for the state of Amazonas-Brazil. Remote Sensing Applications: Society and Environment 17:100278, DOI 10.1016/j.rsase.2019.100278

Wang XY, Li X, Zhu J, Tanajura CAS (2018) The strengthening of Amazonian precipitation during the wet season driven by tropical sea surface temperature forcing. Environ Res Lett 13:094015, DOI 10.1088/1748-9326/aadbb9

Wendisch M, Pöschl U, Andreae MO, Machado LAT, Albrecht R, Schlager H, Rosenfeld D, Martin ST, Abdelmonem A, Afchine A, Araùjo AC, Artaxo P, Aufmhoff H, Barbosa HMJ, Borrmann S, Braga R, Buchholz B, Cecchini MA, Costa A, Curtius J, Dollner M, Dorf M, Dreiling V, Ebert V, Ehrlich A, Ewald F, Fisch G, Fix A, Frank F, Fütterer D, Heckl C, Heidelberg F, Hüneke T, Jäkel E, Järvinen E, Jurkat T, Kanter S, Kästner U, Kenntner M, Kesselmeier J, Klimach T, Knecht M, Kohl R, Kölling T, Krämer M, Krüger M, Krisna TC, Lavric JV, Longo K, Mahnke C, Manzi AO, Mayer B, Mertes S, Minikin A, Molleker S, Münch S, Nillius B, Pfeilsticker K, Pöhlker C, Roiger A, Rose D, Rosenow D, Sauer D, Schnaiter M, Schneider J, Schulz C, de Souza RAF, Spanu A, Stock P, Vila D, Voigt C, Walser A, Walter D, Weigel R, Weinzierl B, Werner F, Yamasoe MA, Ziereis H, Zinner T, Zöger M (2016) ACRIDICON-CHUVA Campaign: Studying Tropical Deep Convective Clouds and Precipitation over Amazonia Using the New German Research Aircraft HALO. Bull Amer Meteor Soc 97(10):1885-1908, DOI 10.1175/BAMS-D-14-00255.1

Wright JS, Fu R, Worden JR, Chakraborty S, Clinton NE, Risi C, Sun Y, Yin L (2017) Rainforest-initiated wet season onset over the southern amazon. Proc Natl Acad Sci (USA) 114(32):8481-8486, DOI 10.1073/pnas.1621516114

Yin L, Fu R, Zhang YF, Arias PA, Fernando DN, Li W, Fernandes K, Bowerman AR (2014) What controls the interannual variation of the wet season onsets over the Amazon? J Geophys Res Atmos 119(5):2314-2328, DOI 10.1002/2013JD021349

Yoon J, Zeng N (2010) An Atlantic influence on Amazon rainfall. Climate Dyn 34:249-264, DOI 10.1007/s00382-009-0551-6

Zemp DC, Schleussner CF, Barbosa HMJ, van der Ent RJ, Donges JF, Heinke J, Sampaio G, Rammig A (2014) On the importance of cascading moisture recycling in south america. Atmos Chem Phys 14(23):13337-13359, DOI 
10.5194/acp-14-13337-2014

Zemp DC, Schleussner CF, Barbosa HMJ, Hirota M, Montade V, Sampaio G, Staal A, Wang-Erlandsson L, Rammig A (2017a) Self-amplified Amazon forest loss due to vegetation-atmosphere feedbacks. Nature Communications 8:14681, DOI 10.1038/ncomms14681

Zemp DC, Schleussner CF, Barbosa HMJ, Rammig A (2017b) Deforestation effects on Amazon forest resilience. Geophys Res Lett 44(12):6182-6190, DOI 10.1002/2017GL072955

Zeng N, Yoon H, MArengo J, Subramaniam A, Nobre C, Mariotti A, Neelin D (2008) Causes and impacts of the 2005 Amazon drought. Environ Res Lett 3:014002, DOI 10.1088/1748-9326/3/1/014002

Zilli M, Carvalho L, Lintner B (2019) The poleward shift of South Atlantic Convergence Zone in recent decades. Climate Dyn 52:2545-2563, DOI 10.1007/s00382$018-4277-1$

Zuffo AM, Steiner F, Aguilera JG, Teodoro PE, Teodoro LPR, Busch A (2020) Multi-trait stability index: A tool for simultaneous selection of soya bean genotypes in drought and saline stress. Journal of Agronomy and Crop Science 206(6):815-822, DOI 10.1111/jac.12409 
A Supplementary figures 


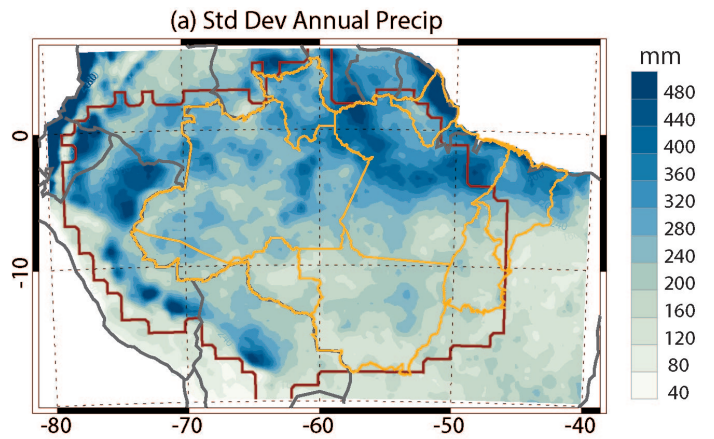

(b) [2008/2009] Precip Anom (flood)

(c) [2009/2010] Precip Anom (Drought)

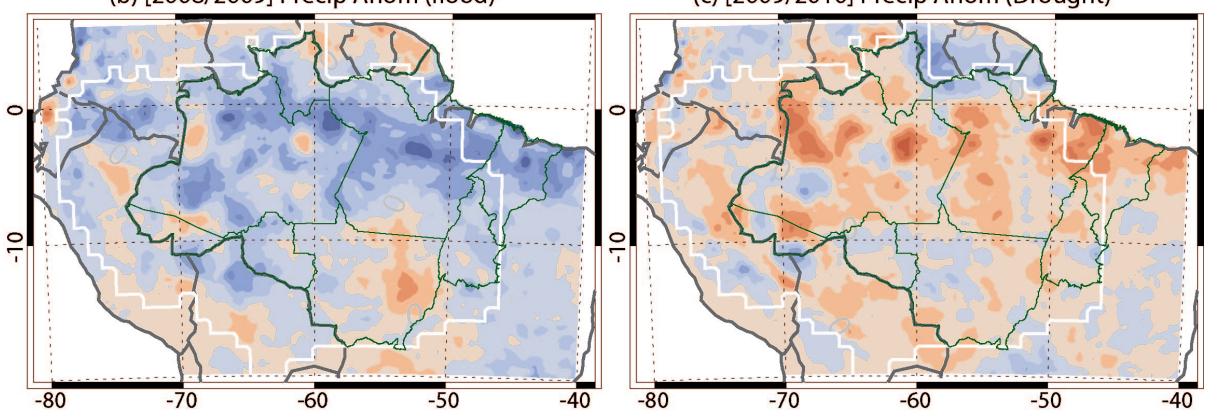

(d) [2013/2014] Precip Anom (flood)

(e) [2015/2016] Precip Anom (Drought)

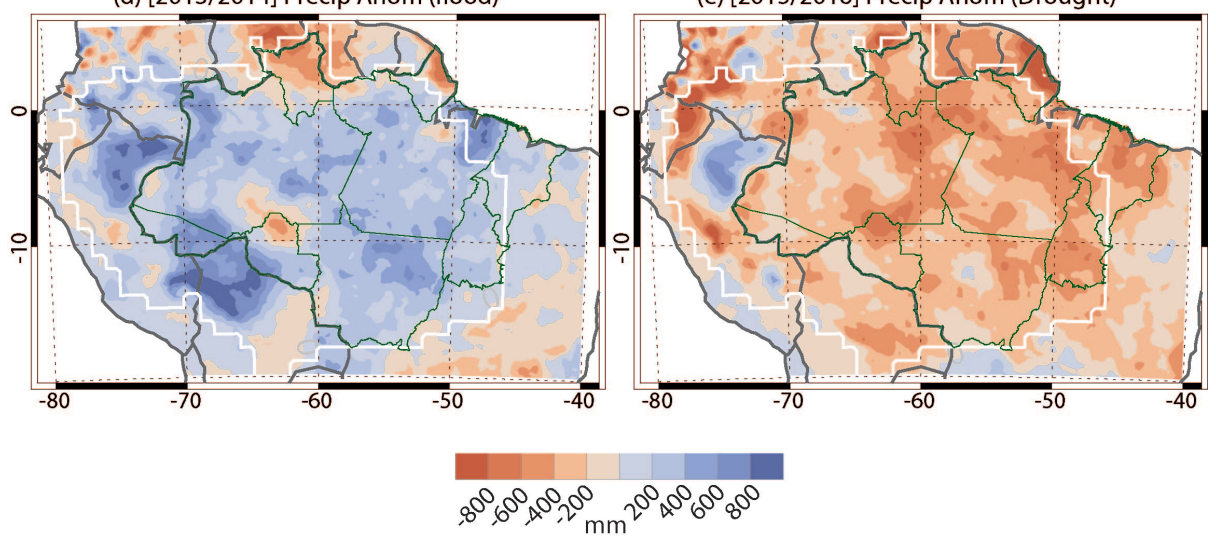

Fig. S1 (a) Standard deviation of the mean annual precipitation, (b) 2008/2009 precipitation anomaly relative to the $1981 / 82-2017 / 18$

mean annual precipitation shown in Fig. 1 (c) same as in (b) but for 2009/2010, (d) same as in (c) but for 2013/2014, (e) same as in (c) but for 2015/2016. (b) and (d) correspond to flood years and (c) and (e) to drought years in the Amazon basin. All variables shown in $\mathrm{mm}$. 
(a) $[2008 / 2009]$ Precip Anom (flood)

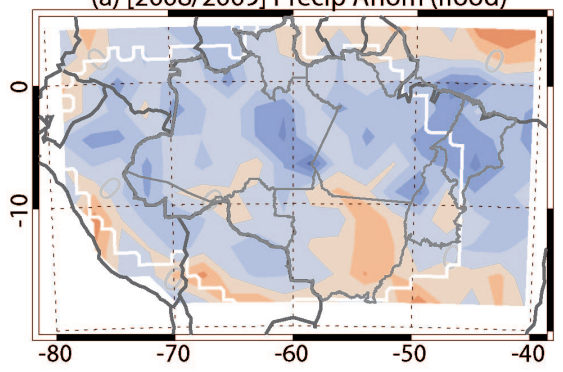

(c) $[2013 / 2014]$ Precip Anom (flood)

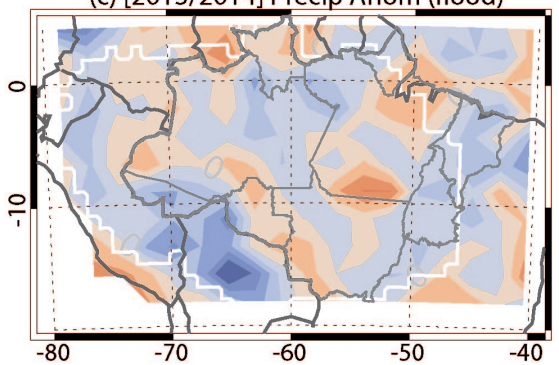

(b) $[2009 / 2010]$ Precip Anom (drought)

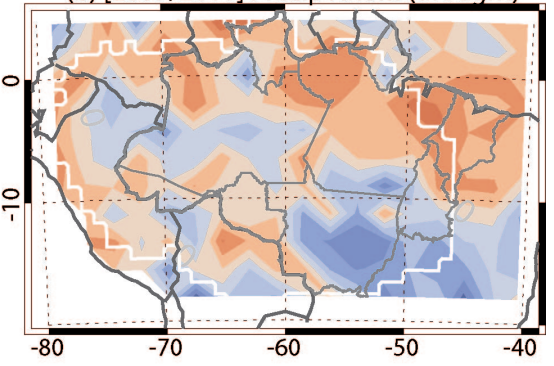

(d) $[2015 / 2016]$ Precip Anom (drought)

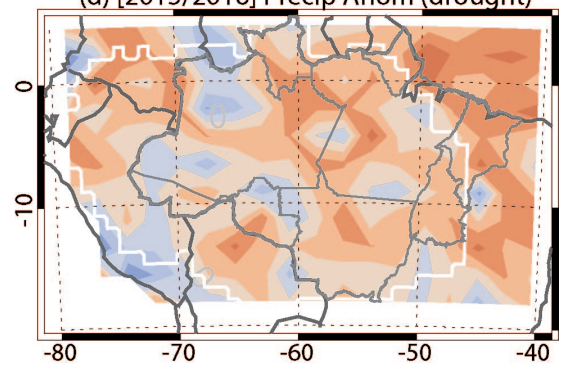

$\begin{array}{llllllllll}-1 & -0.8 & -0.6 & -0.4 & -0.2 & 0 & 0.2 & 0.4 & 0.6 & 0.8\end{array}$

Fig. S2 Yearly mean DC counts anomaly (relative to the 2002-2019 period) for (a) 2008/2009, (b) 2009/2010, (c) 2013/2014, and (d) 2015/2016. (a) and (c) correspond to flood years and (b) and (d) to drought years in the Amazon basin. Anomalies are represented as non-dimensional, e.g., an anomaly of 0.4 represents a $40 \%$ variation relative to the mean. 
(a) Monthly Mean Stdzed DC [5S-2N, 75-50W]

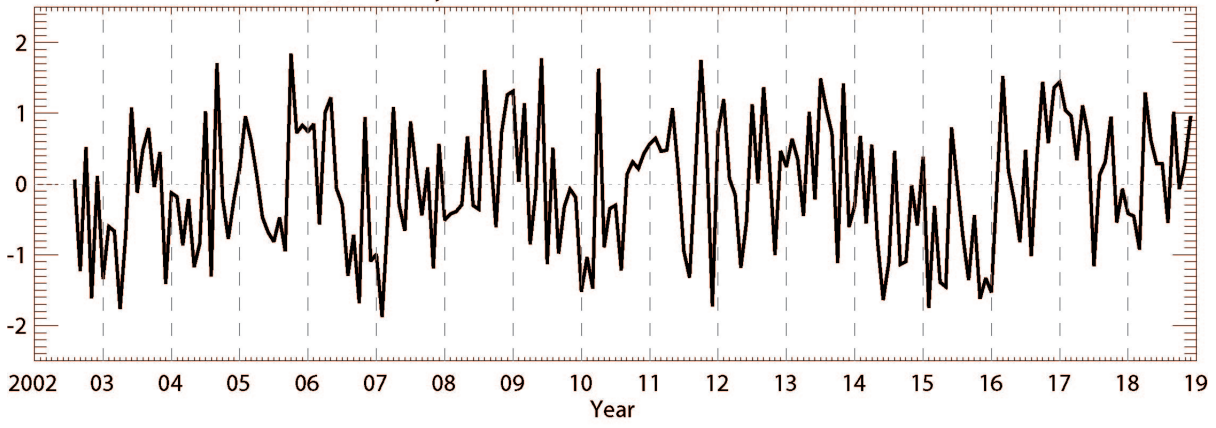

(b) Monthly Mean Stdzed DC [18-10S, 68-50W]

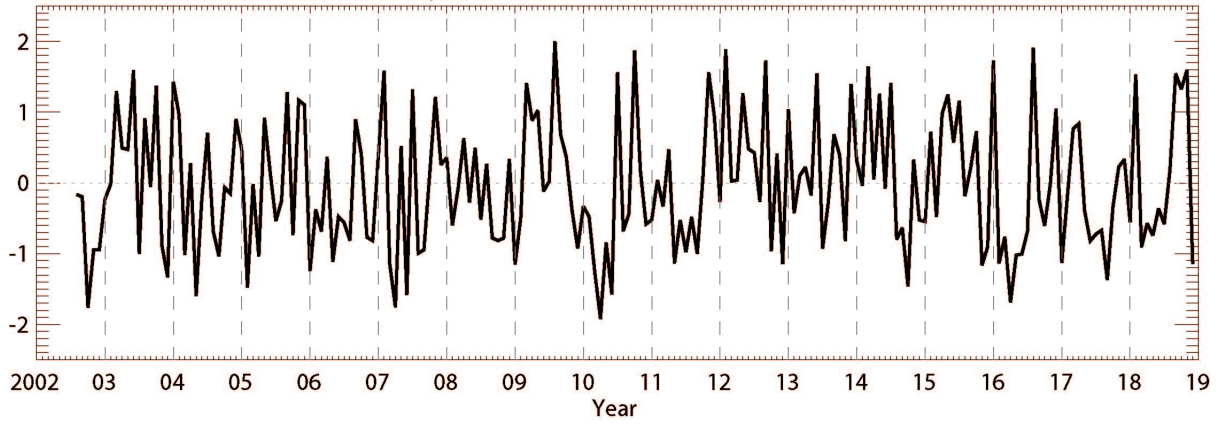

Fig. S3 Time series of standardized DC for (a) Northern and (b) Southern Amazon region. 